\title{
Kapcsolt izotópok (clumped isotopes) a földtudományi kutatásokban
}

\author{
Kele Sándor ${ }^{1}$, BAJNAI Dávid ${ }^{2}$ \\ ${ }^{1}$ MTA Földtani és Geokémiai Intézet, Csillagászati és Földtudományi Kutatóközpont, 1112 Budapest, Budaörsi út 45. (keles@ geochem.hu) \\ ${ }^{2}$ Institut für Geowissenschaften, J. W. Goethe-Universität, 60438 Frankfurt am Main, Altenhöferallee 1. (david.bajnai@em.uni-frankfurt.de)
}

\section{Clumped isotopes in geoscience research}

\begin{abstract}
Clumped isotope geochemistry is a new, dynamically developing field of research, which is based on the temperature-dependent clumping of the ${ }^{13} \mathrm{C}$ and ${ }^{18} \mathrm{O}$ isotopes within one molecule. Using the clumped isotope thermometer, the temperature of the carbonate precipitating fluids can be determined with high precision, based solely on the clumped isotope value $\left(\Delta_{47}\right)$ of carbonates. Besides palaeoclimatology, the method can be used in several research fields in geology, including palaeoceanography, atmospheric research, reservoir geology, geomorphology, structural geology, diagenesis, biogeochemistry, low temperature metamorphic processes, and meteorite research. Due to continuous developments, the number of applications is still significantly increasing. This paper briefly introduces the reader to the principles of clumped isotope geochemistry, reviewing its theoretical basis, and possible applications, and also looks at available calibrations. Furthermore, it provides an overview of the current state-of-the-art.
\end{abstract}

Keywords: stable isotopes, clumped isotopes, geochemistry, thermometry, climate reconstruction, methodology

Összefoglalás

A kapcsoltizotóp-geokémia (clumped isotope geochemistry), egy olyan új, dinamikusan fejlődő kutatási módszer, amely a ${ }^{13} \mathrm{C}$ és a ${ }^{18} \mathrm{O}$ izotópok egy molekulán belüli kapcsolódásának hőmérsékletfüggésén alapszik. Segítségével a karbonátok kiválási hőmérséklete nagy pontossággal meghatározható, kizárólag a karbonát fázis kapcsoltizotóp-értéke $\left(\Delta_{47}\right)$ alapján. A paleoklimatológiai alkalmazások mellett a módszer a geológiai kutatások számos területén (pl. paleooceanográfia, atmoszféra-kutatás, rezervoár-geológia, geomorfológia, tektonika, diagenezis, biogeokémia, alacsony hőmérsékletú metamorf folyamatok, meteorit-kutatás, stb.) alkalmazható, és a múszerfejlesztések révén az alkalmazások köre folyamatosan bóvül. A cikk röviden áttekinti a kapcsolt izotópos módszert, bemutatva annak alapjait, a rendelkezésre álló kalibrációkat, a lehetséges alkalmazási területeket és a témában eddig megjelent publikációkat.

Tárgyszavak: stabilizotóp, kapcsolt izotóp, geokémia, termometria, klímarekonstrukció, módszertan

\section{Bevezetés}

A geokémiai vizsgálatok mára a geológia minden területén — az ôslénytantól a rétegtanon át, a paleoklíma kutatásig - megkerülhetetlenné váltak. Az izotóp-geokémia története a XX. század első felére nyúlik vissza. Az első tömegspektrométer megalkotása 1947-ben Alfred NIER nevéhez fúződik. Ebben az időben publikálta UREY (1947), valamint BIGELEISEN \& MAYER (1947) az izotópok fizikai tulajdonságairól szóló elméleti alapokat és munkáikban már tárgyalták a többszörösen helyettesített (multiply substituted) izotopológokat is. Az izotopológok olyan molekulák, amelyek csak izotópos összetételükben különböznek egymástól (például a ${ }^{12} \mathrm{CO}_{2}$ és a ${ }^{13} \mathrm{CO}_{2}$ egymás izotopológjai). A többszörösen helyettesített izotopológok kettó, vagy több ritka izotópot tartalmaznak (például a ${ }^{12} \mathrm{C}^{18} \mathrm{O}^{16} \mathrm{O}$ egy többszörösen helyettesített $\mathrm{CO}_{2}$ izotopológ). Mivel az ilyen izotopológok rendkívül alacsony előfordulási aránya a mérésüket korábban lehetetlenné tette, a többszörösen helyettesített izotopológok egészen az 1980-as évek végéig érintetlen kutatási területnek számítottak. Az első, kifejezetten erre a témára irányuló kutatás az atmoszféra metánjának izotópos összetételét vizsgálta (MROZ et al. 1989). Az 1990-es évek elején a Caltech-en (California Institute of Technology, Pasadena, Kalifornia, USA) Edwin Schauble és John EILER kezdett az atmoszferikus szén-dioxid több- 
szörösen helyettesített izotopológjaival foglalkozni. Az első sikeres és kellő pontosságú méréseiket az ezredforduló után publikálták (EILER \& SCHAUBle 2004). WANG et al. (2004) és SCHAUble et al. (2006) termodinamikai modelljei teremtették meg az elméleti alapokat a többszörösen helyettesített karbonát molekulák paleotermométerként történő alkalmazásához. A módszer népszerúségét GHosh et al. (2006a) alapozta meg azzal, hogy elsôként vizsgált ismert hőmérsékletủ vízből kivált szerves és szervetlen karbonátokat, és a mért kapcsolt izotópos értékek hőmérsékletfüggése alapján elkészítette a módszer első kalibrációját.

A clumped isotope kifejezést EILER (2007) vezette be. Az elnevezés arra utal, hogy a módszer azokat a karbonátmolekularácson belüli $\mathrm{CO}_{3}^{2-}$ ioncsoportokat vizsgálja, amelyekben két könnyú izotópot $\left({ }^{12} \mathrm{C}\right.$ és $\left.{ }^{16} \mathrm{O}\right)$ a nehéz megfelelőjük $\left({ }^{13} \mathrm{C}\right.$ és ${ }^{18} \mathrm{O}$ ) helyettesít, vagyis ahol a molekularácson belül a nehéz izotópok „,csomókban” helyezkednek el, kapcsolódnak össze (1. ábra). Mivel ennek az angol szakkifejezésnek még nincs elterjedt magyar megfelelője, mi a továbbiakban a „kapcsolt izotóp” kifejezést használjuk.

A hagyományos, kalcit-víz oxigénizotóp-frakcionáción alapuló termométer (UREY 1947, MCCREA 1950, EPSTEIN et al. 1951, 1953) esetében szükség van a fluidum $\delta^{18} \mathrm{O}$ értékének ismeretére is a karbonátok kiválási hőmérsékletének a meghatározásához. Ez általában nem ismert, tehát ahhoz, hogy a paleohőmérséklet számolható legyen, meg kell becsülni. A kapcsolt izotópos módszer jelentősége abban áll, hogy a paleohőmérsékleti számításokhoz kizárólag a karbonát kapcsolt izotópos összetétele szükséges, illetve hogy a karbonát kapcsolt izotóp értéke szinte kizárólag a kiválási hômérséklettől függ, más környezeti tényezóktốl független.

Napjainkban a kapcsolt izotópok módszertani fejlesztése, hőmérsékleti kalibrációja és új alkalmazási területek felfedezése zajlik. Kiemelt cél a hatékonyság és a precizitás növelése, illetve a szükséges mintamennyiség csökkentése (pl. He et al. 2012, BERNASCONI et al. 2013, RosENHEIM et al. 2013, CuI \& WANG 2014, Hu et al. 2014, FiEBig et al. 2016, RöCKMANN et al. 2016). A kalibrációs munkák célja az alkalmazhatóság kiterjesztése szélesebb hőmérsékleti tartományokra (pl. KLUGE et al. 2015), illetve különbözô eredetú és összetételú karbonátokon mért kapcsoltizotóp-értékek hőmérsékletfüggésének meghatározása (pl. WACKER et al. 2014, Kele et al. 2015, WinKelSTERn et al. 2016). További cél, a laboratóriumok közötti kalibráció létrehozása karbonát sztenderdek bevonásával (pl. MECKLER et al. 2014), illetve azonos korrekciós, számítási módszerek használatával (pl. DenNis et al. 2011, DAËRON et al. 2016, JOHN \& BOWEN 2016). Ezeken kívül fontos az elméleti alapok még részletesebb kidolgozása, illetve a gyakorlati eredmények elméleti értelmezése (pl. CAO \& LiU 2012, HiLl et al. 2014, KLUGe \& John 2015, Tripati et al. 2015, WATKINS \& HunT 2015).

Jelen dolgozat célja a kapcsolt izotópos módszer hazai köztudatban történô meghonosítása, illetve a témával kapcsolatos szakkifejezések magyarítása. A kapcsoltizotópgeokémia alapjain túl röviden bemutatjuk azokat a kutatási területeket, ahol a módszer sikeres alkalmazására már van

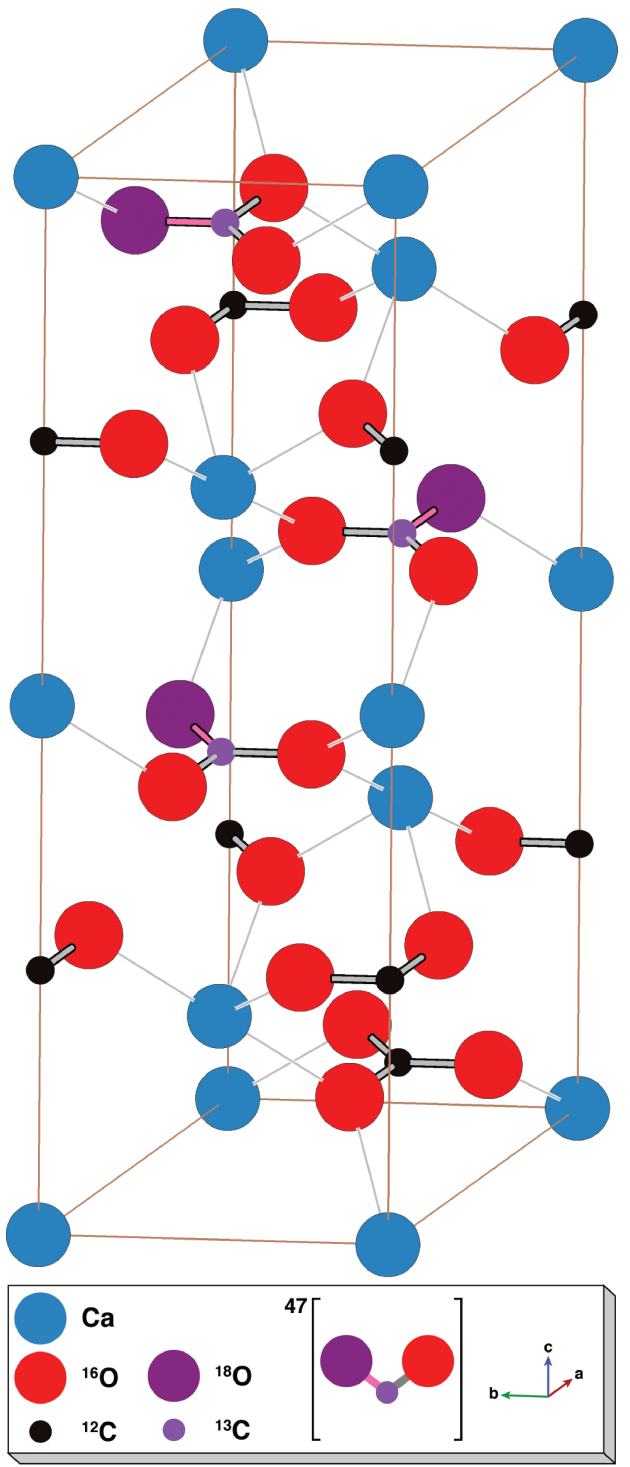

1. ábra. A kalcit kristály elemi cellája. A kapcsoltizotópmódszer azokat a karbonát ioncsoportokat vizsgálja, amelyekben két könnyű izotópot $\left({ }^{12} \mathrm{C}\right.$ és $\left.{ }^{16} \mathrm{O}\right)$ a nehéz megfelelöjük $\left({ }^{13} \mathrm{C}\right.$ és $\left.{ }^{18} \mathrm{O}\right)$ helyettesít. A $\Delta_{47}$ érték azt számszerűsíti, hogy a vizsgált mintában mennyi ${ }^{18} \mathrm{O}-{ }^{13} \mathrm{C}$ kötést tartalmazó, vagyis 47-es tömegszámú izotopológ van ahhoz képest, mint ahogy azt sztochasztikus, azaz véletlenszerủ eloszlás esetén várni lehetne

Figure 1. The unit cell of the calcite crystal. The clumped isotope method studies those carbonate ion groups in the lattice where two light isotopes $\left({ }^{12} \mathrm{C}\right.$ and $\left.{ }^{16} \mathrm{O}\right)$ are substituted by their heavier counterparts $\left({ }^{13} \mathrm{C}\right.$ and $\left.{ }^{18} \mathrm{O}\right)$. The $\Delta_{47}$ value indicates the abundance of the ${ }^{18} \mathrm{O}-{ }^{13} \mathrm{C}$ bond-bearing, mass-47 isotopologues in the sample compared to stochastic distribution

példa. Reményeink szerint a kapcsoltizotóp-geokémia a közeljövőben már nem csak neves külföldi kutatóközpontok kiváltsága lesz, hanem egy hazai szinten is elérhetô új lehetőség, ami tovább növelheti a hazai kutatások nemzetközi versenyképességét. Erre minden esély megvan, mivel az MTA ATOMKI (Debrecen) által elnyert GINOP pályázat segítségével hamarosan hazánkban is elérhetővé válik majd a módszer. 


\section{A kapcsolt izotópok ismertetése}

\section{Módszertan és elméleti alapok}

Izotópoknak nevezzük egy adott elem azonos protonszámú, de különbözô neutronszámú atomjait (isos+topos = azonos+hely), amelyek lehetnek stabilak, illetve radioaktívak. A stabilizotópok aránya fontos geológiai információkat órizhet (pl. ${ }^{11} \mathrm{~B}-\mathrm{pH},{ }^{53} \mathrm{Cr}-$ redox viszonyok), míg a radioaktív izotópok bomlása (pl. ${ }^{14} \mathrm{C}, \mathrm{U} / \mathrm{Th}, \mathrm{U} / \mathrm{Pb}$ ) a képződmények korvizsgálatában tölt be meghatározó szerepet. Mivel a stabilizotóp-geokémiáról már számos összefoglaló tanulmány jelent meg (pl. SHARP 2007, HoEFs 2015), a jelen összefoglalóban csak a kapcsolt izotópokkal foglalkozunk részletesen.

A karbonátok stabilizotóp-geokémiai vizsgálata során általában a minták $\delta^{13} \mathrm{C}$ és $\delta^{18} \mathrm{O}$ értékére vagyunk kíváncsiak. Ezen értékek a mért gázokban azoknak a molekuláknak a gyakoriságától függnek, amelyek egy ritka, nehéz izotópot tartalmaznak (pl. ${ }^{13} \mathrm{C}^{16} \mathrm{O}^{16} \mathrm{O},{ }^{12} \mathrm{C}^{18} \mathbf{O}^{16} \mathrm{O}$ ). Vannak azonban olyan, nagyon alacsony koncentrációban előforduló izotopológok is, amelyek egynél több ritka izotópot tartalmaznak (pl. ${ }^{13} \mathbf{C}^{18} \mathbf{O}^{16} \mathrm{O},{ }^{12} \mathrm{C}^{18} \mathbf{O}^{17} \mathbf{O}$ ) (HoEfs 2015 és további hivatkozások benne) (I. táblázat). Az ilyen, többszörösen helyettesített izotopológok egyedi, a leggyakoribb izotopológoktól eltérő termodinamikai tulajdonságokkal (kötés vibrációs frekvencia, nullponti energia, közeli infravörös abszorpciós színkép) rendelkeznek. A kapcsolódás következtében a többszörösen

I. táblázat. A stabil szén- és oxigénizotópok relatív előfordulási aránya (RoSMAN \& TAYLOR 1998), illetve a szén-dioxid izotopológjainak elöfordulási aránya, sztochasztikus, azaz véletlenszerű eloszlás esetén (EILER 2007)

Table I. Relative abundances of the stable oxygen and carbon isotopes (ROSMAN \& TAYLOR 1998) and the relative abundances of carbon-dioxide isotopologues for stochastic distribution (EILER 2007)

\begin{tabular}{|c|c|c|}
\hline $\begin{array}{l}\text { C izotópok } \\
\text { C isotopes }\end{array}$ & $\begin{array}{l}\text { atomtömeg } \\
\text { atomic weight }\end{array}$ & $\begin{array}{l}\text { gyakoriság } \\
\text { rel. abundance }\end{array}$ \\
\hline${ }^{12} \mathrm{C}$ & 12 & $98,93 \%$ \\
\hline${ }^{13} \mathrm{C}$ & 13 & $1,07 \%$ \\
\hline $\begin{array}{l}\text { O izotópok } \\
\text { O isotopes }\end{array}$ & $\begin{array}{l}\text { atomtömeg } \\
\text { atomic weight }\end{array}$ & $\begin{array}{l}\text { gyakoriság } \\
\text { rel. abundance }\end{array}$ \\
\hline${ }^{16} \mathrm{O}$ & 16 & $99,757 \%$ \\
\hline${ }^{17} \mathrm{O}$ & 17 & $0,038 \%$ \\
\hline${ }^{18} \mathrm{O}$ & 18 & $0,205 \%$ \\
\hline $\begin{array}{l}\mathrm{CO}_{2} \text { izotopológok } \\
\mathrm{CO}_{2} \text { isotopologues }\end{array}$ & $\begin{array}{l}\text { molekulatömeg } \\
\text { molecular weight }\end{array}$ & $\begin{array}{l}\text { gyakoriság } \\
\text { rel. abundance }\end{array}$ \\
\hline${ }^{16} \mathrm{O}-{ }^{12} \mathrm{C}-{ }^{16} \mathrm{O}$ & 44 & $98,40 \%$ \\
\hline${ }^{16} \mathrm{O}-{ }^{13} \mathrm{C}-{ }^{16} \mathrm{O}$ & 45 & $1,11 \%$ \\
\hline${ }^{17} \mathrm{O}-{ }^{12} \mathrm{C}-{ }^{16} \mathrm{O}$ & 45 & 748 ppm \\
\hline${ }^{18} \mathrm{O}-{ }^{12} \mathrm{C}-{ }^{16} \mathrm{O}$ & 46 & $0,40 \%$ \\
\hline${ }^{17} \mathrm{O}-{ }^{13} \mathrm{C}-{ }^{16} \mathrm{O}$ & 46 & $8,4 \mathrm{ppm}$ \\
\hline${ }^{17} \mathrm{O}-{ }^{12} \mathrm{C}-{ }^{17} \mathrm{O}$ & 46 & $0,142 \mathrm{ppm}$ \\
\hline${ }^{18} \mathrm{O}-{ }^{13} \mathrm{C}-{ }^{16} \mathrm{O}$ & 47 & 44,4 ppm \\
\hline${ }^{18} \mathrm{O}-{ }^{12} \mathrm{C}-{ }^{17} \mathrm{O}$ & 47 & 1,5 ppm \\
\hline${ }^{17} \mathrm{O}-{ }^{13} \mathrm{C}-{ }^{17} \mathrm{O}$ & 47 & 1,6 ppb \\
\hline${ }^{18} \mathrm{O}-{ }^{12} \mathrm{C}-{ }^{18} \mathrm{O}$ & 48 & $3,96 \mathrm{ppm}$ \\
\hline${ }^{17} \mathrm{O}-{ }^{13} \mathrm{C}-{ }^{18} \mathrm{O}$ & 48 & $16,8 \mathrm{ppb}$ \\
\hline${ }^{18} \mathrm{O}-{ }^{13} \mathrm{C}-{ }^{18} \mathrm{O}$ & 49 & $44,5 \mathrm{ppb}$ \\
\hline
\end{tabular}

helyettesített izotopológok statisztikailag dúsulnak az összes izotóp tisztán véletlenszerú eloszlásához képest. A sztochasztikus eloszlástól való eltérések általában 1\%-on belüliek és a természetben végbemenő izotópfrakcionációs folyamatokból adódhatnak (WANG et al. 2004).

Egy nehézizotóp könnyưizotóppal való helyettesítése a molekulák stabilitását és a reakcióik kinetikáját is befolyásolja. Egy kétatomos molekulában (pl. $\mathrm{H}_{2}$ ) a molekula által elérhetô legalacsonyabb energiaállapot potenciális energiája csökken egy könnyú izotóp nehéz izotóppal való helyettesítése esetén: két nehéz izotóp (pl. D-D) közötti kötés nullponti energiája alacsonyabb, mint egy nehéz és egy könnyú izotóp közti kötésé (pl. D-H), ami alacsonyabb, mint két könnyú izotóp közötti kötés nullponti energiája (UREY 1947; BigELEISEN 1955, 1965) (2. ábra). A rezgési energia csökkenése két könnyú izotóp nehéz izotópokkal való helyettesítése esetén gyakran meghaladja az egyszeri helyettesítés kétszeresét (UREY 1947, BIGELEISEN 1955, EILER 2007). Ez a kis különbség egy olyan termodinamikai hatóerő, ami elősegíti a nehéz izotópok többszörösen helyettesített izotopológokban való kapcsolódását, hiszen az energiaminimumra való törekvés miatt egy zárt rendszerben előnyösebb a D-D kötések kialakulása, mint a H-D kötéseké. Ez a hatás felírható egy olyan homogén izotópcserereakcióként, amibe csak egy fázis izotopológjai vannak bevonva (ScHAUBLE et al. 2006):

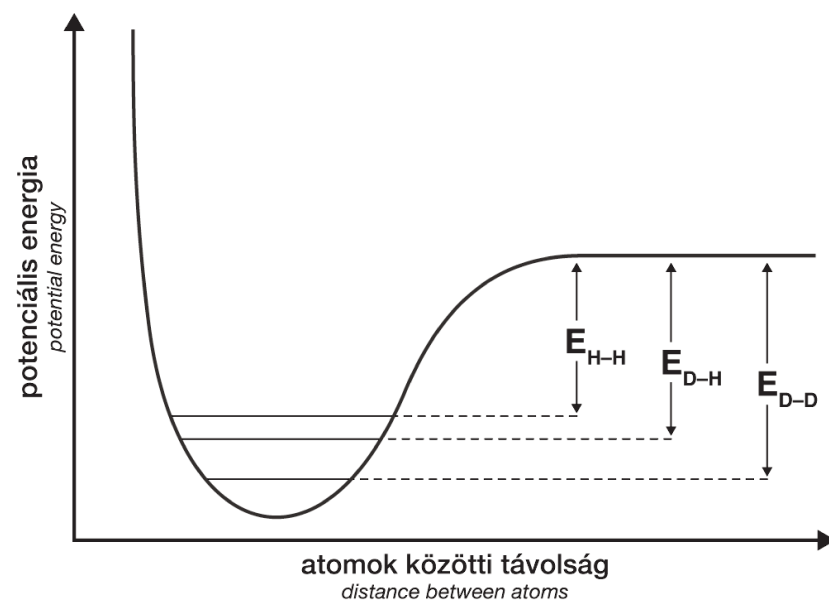

2. ábra. $\mathrm{A} \mathrm{H}_{2}$ molekula sematikus potenciális energia (Morse potenciál) görbéje. A kvantumfizika törvényei értelmében egy molekula által elérhető legalacsonyabb energiaállapot nem a potenciális energiagörbének a minimumpontján van, hanem felette. Egy $\mathrm{H}_{2}$ molekula nullponti energiája csökken egy nehéz izotóp helyettesítésével, és még tovább csökken, ha mindkét atomot nehéz izotóp helyettesíti. Két nehéz izotópos helyettesítés esetén a molekula nullponti energiájának a csökkenése (ED-D) kicsivel meghaladja az egy nehéz izotópos helyettesítés által okozott nullponti energia csökkenés (EH-D) kétszeresét (BIGELEISEN 1965 és EILER 2007 nyomán)

Figure 2. Schematic potential energy (Morse potential) curve of the $\mathrm{H}_{2}$ molecule. According to the quantum theory, the lowest potential energy level of the molecule is above the minimum of the potential energy curve. The zero-point energy is reduced with a single heavy isotope substitution $(E H-D)$ and reduced further with a second heavy isotope substitution (ED-D). The decrease in zero-point energy after a second heavy isotope substitution is slightly greater than two times the decrease in the zero-point energy after only one heavy isotope substitution, therefore the ED-D substitution is the energetically preferable situation (Redrawn after BIGELEISEN [1965] and EILER [2007]) 
(1) ${ }^{13} \mathrm{C}^{16} \mathrm{O}_{3}{ }^{2-}+{ }^{12} \mathrm{C}^{18} \mathrm{O}^{16} \mathrm{O}_{2}{ }^{2-}={ }^{13} \mathrm{C}^{18} \mathrm{O}^{16} \mathrm{O}_{2}{ }^{2-}+{ }^{12} \mathrm{C}^{16} \mathrm{O}_{3}{ }^{2-}$

Ezzel szemben a hagyományos stabilizotóp-termometria esetében két fázis van jelen:

(2) $\mathrm{H}_{2}{ }^{18} \mathrm{O}+\mathrm{CaC}^{16} \mathrm{O}_{3}=\mathrm{H}_{2}{ }^{16} \mathrm{O}+\mathrm{CaC}^{18} \mathrm{O}^{16} \mathrm{O}_{2}$

A kapcsoltizotóp-értékek jelölésére a nagy görög delta betú használatos, alsó indexben feltüntetve a vizsgált izotopológ molekulatömegét (pl. $\Delta_{47}$ ). A $\Delta_{47}$ értéket ezrelékben (\%o) szokás megadni (EILER 2007). A $\Delta_{47}$ érték azt számszerúsíti, hogy a vizsgált mintában mennyi ${ }^{18} \mathrm{O}-{ }^{13} \mathrm{C}$ kötést tartalmazó, vagyis 47-es tömegszám/töltés arányú, izotopológ van ahhoz képest, mint ahogy azt sztochasztikus, azaz véletlenszerú eloszlás esetén várni lehetne. Ebból eredően, sztochasztikus eloszlás esetén a $\Delta_{47}=0 \%$ o, és az érték a hőmérséklet csökkenésével növekszik.

A szén-dioxid $\Delta_{47}$ értéke a következóképp határozható meg:

$$
\Delta_{17}=-1000 \ln \left(\frac{\mathrm{K}}{\mathrm{K}}\right)=\left[\left(\frac{\mathrm{R}^{47}}{\mathrm{R}^{47} * 1}\right)\left(\frac{\mathrm{R}^{46}}{\mathrm{R}^{46} * 1}\right)\left(\frac{\mathrm{R}^{45}}{\mathrm{R}^{45} *}\right)\right] \times 1000
$$

ahol K az (1) egyenlet egyensúlyi együtthatója, K* ugyanezen egyenlet egyensúlyi együtthatója sztochasztikus eloszlás esetén, $\mathrm{R}^{47}, \mathrm{R}^{46}$ és $\mathrm{R}^{45}$ a mintában előforduló 47 -es, 46-os és 45-ös tömegszámú izotopológok 44-es tömegszámú izotopológhoz viszonyított arányai, míg az $\mathrm{R}^{47 *}, \mathrm{R}^{46 *}$ és $\mathrm{R}^{45 *}$ ugyanezeket az arányokat jelölik, a minta izotópjainak sztochasztikus eloszlása esetén (EILER 2007). Az R ${ }^{\mathrm{i}}$ értékeket (i=45, 46, 47) egy ismert izotópos összetételú sztenderd gázhoz viszonyítva lehet mérni:

$$
\mathrm{R}^{\mathrm{i}}=\left(\frac{\delta_{\mathrm{i}}}{1000}+1\right) \times \mathrm{R}_{\mathrm{ref}}^{\mathrm{i}}
$$

ahol $\mathrm{R}_{\text {ref }}^{\mathrm{i}}$ a sztenderdként használt gáz ismert izotópos összetételéból számolható, $\delta_{i}$ pedig:

$$
\delta_{\mathrm{i}}=\left(\frac{\mathrm{I}_{\text {minta }}^{\mathrm{i}}}{\mathrm{I}_{\mathrm{ref}}^{\mathrm{i}}}-1\right) \times 1000
$$

ahol I ${ }^{\mathrm{i}}$ a tömegspektrométer által mért intenzitásértékekből számolható. Az $\mathrm{R}^{\mathrm{i} *}$ értékek a minta $\delta^{13} \mathrm{C}$ és $\delta^{18} \mathrm{O}$ értékeiból vezethetôek le feltételezve, hogy a $\delta^{13} \mathrm{C}$ és $\delta^{18} \mathrm{O}$ értékek függetlenek az izotopológok eloszlásától:

$$
\begin{aligned}
& \mathrm{R}^{45 *}=\mathrm{r}^{13}+\mathrm{r}^{17} \\
& \mathrm{R}^{46 *}=2 \times \mathrm{r}^{18}+2 \times \mathrm{r}^{13} \times \mathrm{r}^{17}+\left(\mathrm{r}^{17}\right)^{2} \\
& \mathrm{R}^{47 *}=2 \times \mathrm{r}^{13} \times \mathrm{r}^{18}+2 \times \mathrm{r}^{17} \times \mathrm{r}^{18}+\mathrm{r}^{13} \times\left(\mathrm{r}^{17}\right)^{2}
\end{aligned}
$$

ahol $\mathrm{r}^{13}, \mathrm{r}^{17}$ és $\mathrm{r}^{18}$ a minta ${ }^{13} \mathrm{C} /{ }^{12} \mathrm{C},{ }^{17} \mathrm{O} /{ }^{16} \mathrm{O}$ és ${ }^{18} \mathrm{O} /{ }^{16} \mathrm{O}$ arányait jelölik (Huntington et al. 2009).

\section{A mérés menete}

A mintaelőkészítés és a mérés a különböző laborokban eltérô módon, többféle múszerrel történhet, ezért ebben a fejezetben csak egy általános leírást adunk a folyamatáról. A stabilizotópos mérésekhez hasonlóan a mérés eloott a mintákat homogenizálni kell achátmozsár és törő segítségével. A mérés minden esetben gázfázisból történik, izotóparány- mérő tömegspektrométerrel. A karbonátminták savas feltárásához, illetve a keletkező $\mathrm{CO}_{2}$ gáz tisztításához a legtöbb labor saját fejlesztésú, automatizált rendszert használ. A $\mathrm{CO}_{2}$ gáz fejlesztéséhez általában 2-8 mg tiszta kalciumkarbonátot reagáltatnak tömény (>103\%), 25-90 ${ }^{\circ} \mathrm{C}$ hőmérsékletû foszforsavval. Fontos lépés a képződött $\mathrm{CO}_{2}$ gáznak a fő szennyező vízmolekuláktól való elkülönítése, amelyek új termodinamikai egyensúlyi állapotot hozhatnak létre ( $r e-$ equlibration) a $\mathrm{CO}_{2}$ molekulákban, ezzel megváltoztatva azok kapcsolt izotópos összetételét, valamint a tömegspektrométer ionforrásában izotópcsere-reakciók folytán befolyásolhatják a 47-es tömegszám/töltés arányú ionok intenzitását. A savval történő reakció közben a $\mathrm{CO}_{2}$ gázt folyékony nitrogénnel hútött $\left(-200{ }^{\circ} \mathrm{C}\right)$ csapdában fagyasztják ki. A reakció után a szilárd $\mathrm{CO}_{2}$-t tartalmazó üvegcsapdát -80 ${ }^{\circ} \mathrm{C}$-os etanolba mártják, aminek következtében a $\mathrm{CO}_{2}$ szublimál, míg a víz a hútött csapdában marad. A szublimált gázt egy következő folyékony nitrogénnel hưtött csapdában fagyasztják ki. Ezt a folyamatot, a legjobb hatékonyság érdekében többször meg kell ismételni. További potenciális szennyezők, mint például a szénhidrogének, vagy halokarbonok (pl. CCl) PoraPakQ abszorbenssel töltött, alacsony hőmérsékletû́ gázkromatográfiás oszloppal távolíthatók el (pl. Schmid et al. 2012, PETERSEN et al. 2016a). Erre azért van szükség, hogy el lehessen kerülni a $\mathrm{CO}_{2}$-al azonos tömegszám/töltés arányú (44-47) molekulák által okozott interferenciákat a mérés során, amelyek hamis, túlságosan magas $\Delta_{47}$ értékeket eredményezhetnek.

A mért nyers adatokat a savas reakció, a tömegspektrométer forrásában lejátszódó frakcionációs folyamatok, illetve a tömegspektrométer tulajdonságai és állapota miatt korrigálni kell. A tömegspektrométer detektorjain a 44-es tömegszám/töltés arányú ionsugárból származó másodlagos elektronok negatív hátteret okoznak. A háttér korrekció (PBL - Pressure Baseline Correction, background correction) során ez a hatás kiküszöbölhető, például a 49-es tömegszám/töltés intenzitásának és a 47-es tömegszám/ töltés intenzitásának az összevetésével (BERNASCONI et al. 2013, FIEBIG et al. 2016). A tömegspektrométer ionforrásállapotától függően számolni kell a $\delta_{47}-\Delta_{47}$ értékek közötti korrelációval (scale compression, 5. egyenlet). A hevített gáz korrekció (heated and equlibrated gas correction) során különbözô stabil izotópos összetételú $\mathrm{CO}_{2}$ gázokat fütenek fel $1000{ }^{\circ} \mathrm{C}$-ra több órán keresztül, hogy elérjék a sztochasztikus eloszlást $\left(\Delta_{47}=0,0266 \%\right.$ o), illetve hoznak egyensúlyi állapotba $25{ }^{\circ} \mathrm{C}$-on $\quad\left(\Delta_{47}=0,9252 \%\right.$ o $)$, és ábrázolják az eredményt egy-egy $\delta_{47}-\Delta_{47}$ diagramon (WANG et al. 2004, DenNis et al. 2011). Több ilyen gáz mérése után meghatározható a $\Delta_{47}$ skála két végpontján a $\delta_{47}-\Delta_{47}$ regressziós egyenesek tengelymetszete. A két tengelymetszetet az elfogadott tengelymetszetekkel összevetve kiszámolható a múszer adott időszakra vonatkozó empirikus transzfer függvénye (ETF - Empirical Transfer Function). Ennek segítségével a mért $\Delta_{47}$ értéket az abszolút referenciakeretben (ARF-Absolute Reference Frame) lehet megadni, ami így már laborok között is összevethető (DENNIS et al. 2011). A mért $\Delta_{47}$ értékek függenek továbbá a 
foszforsavas reakció frakcionáló hatásától, amit a sav töménysége és hőmérséklete határoz meg. Egyes laborok között nem csak a reakció hőmérsékletében, hanem a használt frakcionációs együtthatókban is különbség lehet. Adatok összehasonlítása esetén különös figyelmet kell fordítani arra, hogy a laborok az egyes korrekciókat hogyan végezték el és milyen együtthatókat alkalmaztak.

\section{Müszerek}

A múködő, saját kalibrációval rendelkező, publikálható adatokat produkáló laboratóriumok száma jelenleg még alacsony, aminek egyik oka, hogy a méréshez különlegesen érzékeny múszerek szükségesek. Ugyan történtek mérési kísérletek Finnigan ${ }^{\mathrm{TM}}$ Delta XP (YoshiDA et al. 2013) és Thermo Scientific ${ }^{\mathrm{TM}}$ Delta V Plus (SCHMID 2011) tömegspektrométerrel is, a mérésekhez leggyakrabban használt és felépítését, érzékenységét tekintve leginkább megfelelő múszer a Thermo Fisher ${ }^{\mathrm{TM}}$ MAT 253 izotóparányt méró tömegspektrométer. Ez utóbbi egy eredetileg a hagyományos izotópok mérésére tervezett kettős bemenetû (dualinlet) múszer, amelynek nagy az érzékenysége (1 ion / 600 $\mathrm{CO}_{2}$ molekula) és $10 \mathrm{kV}$ a gyorsítási potenciálja (szemben a Delta XP és a Delta V Plus 3 kV-jával). Újabb változata a MAT 253 Plus nagyobb érzékenységú detektorokkal rendelkezik, amelyek csökkentik a másodlagos elektronok által okozott negatív hátteret. Ez a múszer egy további detektort is tartalmaz, ami a hozzá tartozó szoftver segítségével automatizálja a negatív háttér korrekcióját. Alternatíva a kapcsolt izotópok mérésére kifejlesztett Nu Instruments $^{\mathrm{TM}}$ Perspective IS tömegspektrométer (pl. Tripati Lab - UCLA, Yeung Lab, Rice University, USA). Léteznek továbbá „házi-készítésú” tömegspektrométerek is, mint például a Paul DENNIS (University of East Anglia, UK) által készített MIRA (Multi-Isotope Ratio Analyser).

A tömegspektrométert egy Thermo Scientific ${ }^{\mathrm{TM}}$ Kiel IV karbonát feltáró egységhez (pl. ETH Zürich), vagy más fejlesztésû minta-előkészítő berendezéshez csatolva a mérés automatizálható, a mintaszám növelhető, a szükséges anyagmennyiség pedig csökkenthető (PASSEY et al. 2010, SCHMID \& BERNASCONi 2010, Hu et al. 2014).

\section{Kalibrációk}

A $\Delta_{47}$ értékek és a hőmérséklet közötti összefüggést először WANG et al. (2004) határozta meg elméleti úton $\mathrm{CO}_{2}$ gázra, ezt követően pedig ScHAUbLE et al. (2006) karbonátokra. GHosh et al. (2006a) $1-50{ }^{\circ} \mathrm{C}$ közötti hőmérsékleti tartományra kidolgozott kalibrációja volt az első publikált $\Delta_{47}$ T összefüggés, ami megmutatta, hogy az elméleti összefüggés a gyakorlatban is érvényes. Ezt követően tanulmányok sora készült modern biogén minták alapján. GHOSH et al. (2007) aragonitos hal otolithokat vizsgált, de készült kalibráció felszíni és mélytengeri korallok (THIAGARAJAN et al. 2011, SAENGER et al. 2012), foraminiferák és kokkolitok (TRIPATI et al. 2010, GRAUEL et al. 2013), fog bioapatit (EAGLE et al. 2010), kagylók és brachiopodák (HunTINGTON et al. 2009, EAGLE et al. 2013, Henkes et al. 2013, CAME et al. 2014, WACKER et al. 2014) és szintetikus karbonátok (GHOSH et al. 2006a, DENNIS \& SCHRAG 2010, TANG et al. 2014, KLUGE et al. 2015, Kelson et al. 2017) alapján is (3. ábra). Az új kalibrációk egyrészt növelték a hőmérsékleti tartományt (pl. KELE et al. 2015, KLUGE et al. 2015, BoNIFACIE et al. 2017), másrészt rámutattak, hogy a kalibrációk nem csak anyag, hanem módszer, tehát labor specifikusak is lehetnek. A kísérleti úton előállított szintetikus karbonátokon készült kalibrációk kevésbé alkalmasak a természetben képződő karbonátok esetén, mivel nehéz modellezni a természetben lejátszódó folyamatokat.

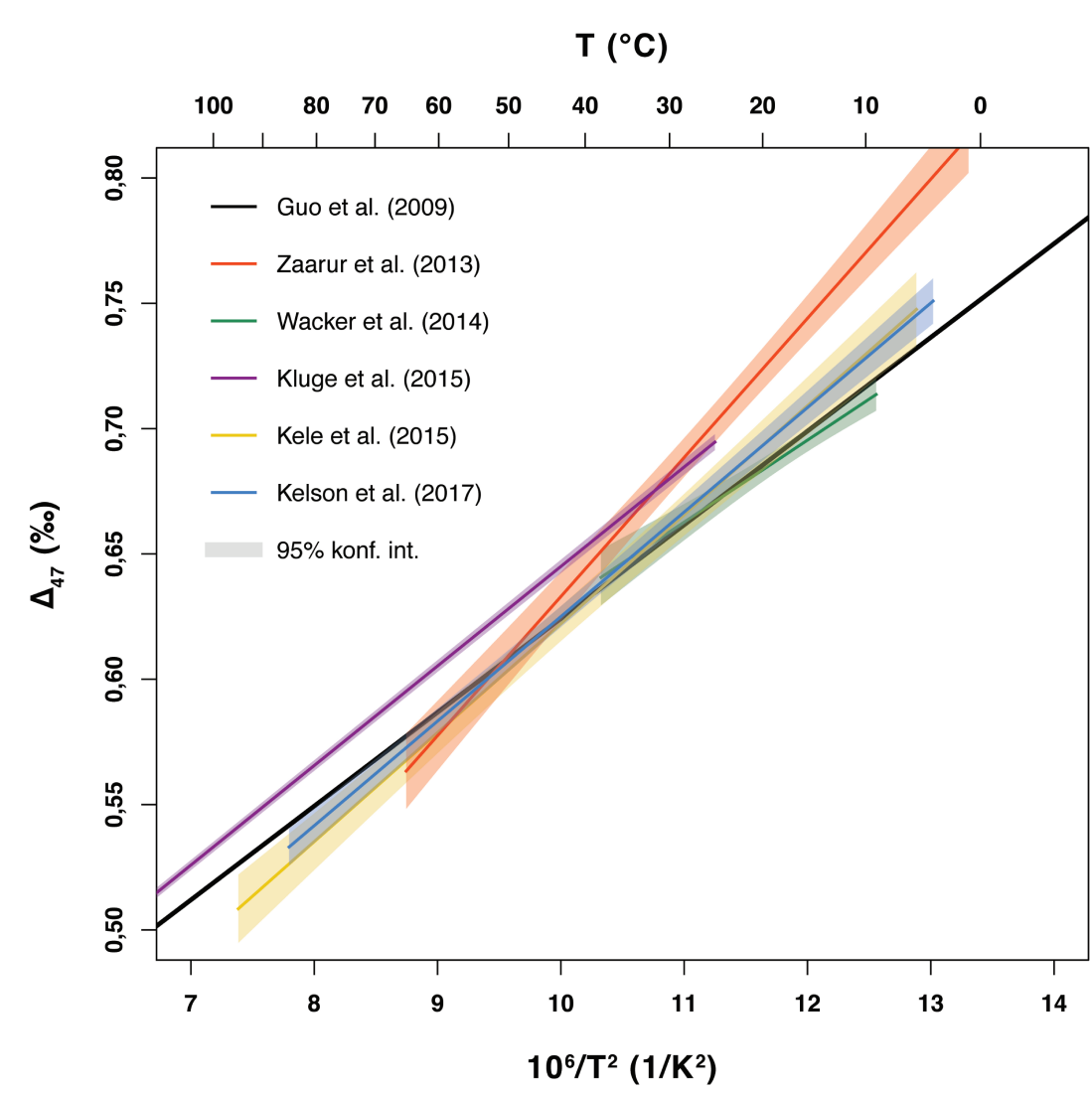

3. ábra. A kapcsolt izotóp termométer fontosabb kalibrációs görbéi Guo et al. (2009; elméleti kalibráció), ZAARUR et al. (2013), WACKER et al. (2014), KLUGE et al. (2015), KelE et al. (2015) és KELSON et al. (2017) alapján. A kalibrációs görbék tengelymetszetei egységesen, 0,069\%o-es $25-90{ }^{\circ} \mathrm{C}$ közötti sav frakcionációs együtthatóval vannak megadva

Figure 3. Calibration curves for the clumped isotope thermometer according to Guo et al. (2009; theoretical line), WACKER et al. (2014), KLUGE et al. (2015), KELE et al. (2015), and KELSON et al. (2017). The intercepts of the equations are normalised to an acid fractionation factor of $0.069 \%$ between $25^{\circ} \mathrm{C}$ and $90{ }^{\circ} \mathrm{C}$ 
A kalibrációs egyenesek közti lényeges különbség az egyenesek meredeksége (a hômérsékleti érzékenységük), valamint a hőmérsékleti tartománya. A kalibrációs egyenesek meredeksége és metszéspontja közötti eltérések oka még nem tisztázott. A $25^{\circ} \mathrm{C}$-os foszforsavval történó feltárást alkalmazó laboratóriumokban készuilt kalibrációk (pl. GHOSH et al. 2006a, TRIPATI et al. 2010, ZAARUR et al. 2013, CAME et al. 2014) meredekebbek, míg a $90{ }^{\circ} \mathrm{C}$-os foszforsavval történő feltárást alkalmazók (DENNIS \& SCHRAG 2010, HenKes et al. 2013, EAGLE et al. 2013, WACKER et al. 2014, KLUGE et al. 2015) laposabbak, a $70{ }^{\circ} \mathrm{C}$-os feltárás esetében pedig a $25^{\circ} \mathrm{C}$-os és $90{ }^{\circ} \mathrm{C}$-os meredekségek közé esnek (KELE et al. 2015). Guo et al. (2009) elméleti kalibrációja a $90{ }^{\circ} \mathrm{C}$-os foszforsavval történő feltárást alkalmazó laboratóriumokban készített kalibrációkhoz áll közelebb. Valószínú, hogy az alacsonyabb hőmérsékletű feltárás során másodlagos folyamatok (pl. új egyensúly a savból származó vízmolekulák hatására) befolyásolják a $\mathrm{CO}_{2}$ kapcsolt izotópos értékét (WACKER et al. 2013). Ezzel szemben AFFEK \& ZAARUR (2014) és PETRIZZo \& Young (2014) munkái, valamint DefLIESE et al. (2015) és KeLSON et al. (2017) kísérletei is megkérdőjelezik a foszforsav hőmérsékletének jelentőségét. A kalibrációs egyenesek tengelymetszetei közötti eltérés származhat a különböző szerzők által (a savas feltárás miatt) használt karbonát-gáz közötti sav frakcionációs együtthatók (AFF — Acid Fractionation Factor) különbségéből. Például, a Guo et al. (2009) által elméleti úton meghatározott sav frakcionációs együttható $25^{\circ} \mathrm{C}$ és $90{ }^{\circ} \mathrm{C}$ között 0,069\%o, míg ugyanerre a HENKEs et al. (2013) által gyakorlati úton tapasztalt sav frakcionációs együttható 0,092\%o. A MüLLER et al. (2017) által meghatározott $25^{\circ} \mathrm{C}$ és $70{ }^{\circ} \mathrm{C}$ közötti sav frakcionációs együttható $0,063 \%$.

Dolomitok savas reakciója során végbemenô frakcionációt MuRRAY et al. (2016) vizsgálta. Még nem alakult ki egyetértés, hogy melyik frakcionációs együttható a helyes, ezért a különböző szerzők által megadott kalibrációs egyenesek eltérő karbonát-gáz frakcionációs együtthatóval készültek. Az egyes kalibrációk összehasonlításához figyelembe kell venni az alkalmazott $\mathrm{CaCO}_{3}-\mathrm{CO}_{2}$ frakcionációs együtthatók közötti különbségeket (WACKER et al. 2013, 2014). Kelson et al. (2017) kísérletei szerint a $25^{\circ} \mathrm{C}$ és $90^{\circ} \mathrm{C}$ közötti hőmérsékletû savval feltárt minták $\Delta_{47}$ értékei (konstans sav frakcionációs együtthatóval történő korrekciót követően) a hibahatáron belül esnek.

A természetben képződő travertínók, mésztufák és a termálkutak csöveiben kivált karbonátok kiváló alapot nyújtanak a kapcsolt izotópos módszer hőmérsékleti kalibrációjára, ugyanis tág hőmérsékleti határok között és változatos pH, elektromos vezetôképesség (EC), és kiválási sebesség mellett képződnek, így alkalmasak az említett tényezők, valamint az ásványos összetétel (kalcit, aragonit) $\Delta_{47}$ (és $\delta^{18} \mathrm{O}$ ) értékekre gyakorolt hatásának tanulmányozására is (KELE et al. 2015). A forráskilépési pontok környékéről, valamint a kisebb tavacskákból begyújtött travertínók, mésztufák és barlangi karbonátok $\Delta_{47}$ értékei erôs $\left(\mathrm{r}^{2}>0,95\right)$ hőmérsékletfüggést mutatnak és a korábbiaktól eltérő meredekségú és jóval nagyobb hőmérsékleti tarto- mányt $\left(5-95{ }^{\circ} \mathrm{C}\right)$ átfogó hőmérsékleti kalibrációs görbét jelölnek ki (KELE et al. 2015). A travertínókon alapuló kalibráció az ETH Zürich laborjában alkalmazott módszerrel született, ahol $70{ }^{\circ} \mathrm{C}$-os foszforsavval történik a karbonát feltárása. Az előzetes eredmények alapján a $\Delta_{47}$ értékékek függetlenek a víz pH-jától, valamint az ásványos összetételtôl, de enyhe függést mutatnak a kiválási sebességgel is. A recens travertínókon alapuló empirikus $\Delta_{47}-\mathrm{T}$ hőmérsékleti kalibrációs görbét többféle karbonát típuson, például édesvízi mészköveken, kagylókon, brachiopodákon (KELE et al. 2015), csigákon (GRAUEL et al. 2016), dolomitokon (Millán et al. 2016), aragonitos kagylóhéjon (RITTER et al. 2017) és karbonátos konkréciókon (HEIMHOFER et al. 2017) is sikerrel alkalmazták.

KELSON et al. (2017) kísérleteket végzett a laboratóriumi körülmények között készített karbonátokon alapuló kalibrációk közötti eltérések okainak (pl. savas feltárás hőmérséklete) felderítésére. 56 szintetikus karbonát mintát vizsgáltak a 4-85 ${ }^{\circ} \mathrm{C}$ hőmérsékleti tartományban különféle $\mathrm{CO}_{2}$ kigázosodási módszereket használva, szénsav-anhidráz enzim bevonásával és anélkül, $25^{\circ} \mathrm{C}$ és $90^{\circ} \mathrm{C}$ hômérsékletű savas feltárást alkalmazva. Arra jutottak, hogy az alkalmazott módszernek nincs hatása a $\Delta_{47}$ értékekre, kivéve az olyan eseteket, amikor nagyon gyors a kigázosodás (pl. a cseppkövek esetében, a nagy $\mathrm{pCO}_{2}$-vel jellemezhető csepegővízből történő kiváláskor). KELSON et al. (2017) a nagyszámú mintán alapuló laborkísérletei alapján egy olyan laboratóriumi (és univerzális) kalibrációt javasolt, ami a természetben, különféle módon, egyensúly közeli feltételek között képződő mintákra is alkalmazható a $4-85{ }^{\circ} \mathrm{C}$ hômérsékleti és 5-10 között pH tartományban, megjegyezve, hogy a kalibrációhoz leginkább illeszkedő, természeti mintákon alapuló görbe KeLE et al. (2015) édesvízi mészköveken alapuló kalibrációja, ahol a kinetikus frakcionáció mértéke szinte elhanyagolhatóan alacsony, egyensúlyközeli állapotot jelezve.

\section{Alkalmazási területek és esettanulmányok}

A kapcsolt izotópos mérések esetében különös figyelmet kell fordítani a minta megőrződésének vizsgálatára. A hagyományos (pl. katód-lumineszcencia, pásztázó elektronmikroszkóp) vizsgálatokon túl szükség lehet a nano mérettartományra irányuló vizsgálatokra (pl. EBSD Electron Backscatter Diffraction, visszaszórt elektron diffrakció) is. Úgy is megváltozhat egy karbonát kapcsolt izotópos összetétele, tehát a ${ }^{18} \mathrm{O}-{ }^{13} \mathrm{C}$ kötések relatív aránya, hogy az izotópok aránya $\left(\delta^{13} \mathrm{C}\right.$ és $\left.\delta^{18} \mathrm{O}\right)$ nem változik. Szilárd fázisú diffúzió során a karbonátcsoportokon belül felbomlanak az eredeti C-O kötések, és új C-O kötések jönnek létre a szomszédos atomok között. HENKEs et al. (2014) laboratóriumi kísérletei és számításai alapján azokban a kalcitkristályokban megy végbe jelentős mértékben szilárd fázisú diffúzió, amelyek $10^{6}-10^{8}$ éven keresztül $100{ }^{\circ} \mathrm{C}$ körüli hőmérsékleten voltak eltemetve. Akár azonos rétegtani szintből származó, de különféle karbonátok is adhatnak 
eltérő átalakulási hômérsékletet. Az eltemetés időtartamán és maximális hômérsékletén kívül, például biogén karbonát esetén az eredeti porozitás, valamint az eredeti nyomelem (pl. Mg)-tartalom is hatással lehet a szilárd fázisú diffúzió mértékére (PASSEY \& HeNKes 2012, SHENTON et al. 2015). Aragonit minták esetén a kalcitmintákhoz képest is óvatosabban kell eljárni, mivel a kézi fúróval történő mintázás során keletkező hő hatására az aragonit kalcittá alakulhat és a minta 10\%-ának az átalakulása is már jelentôs mértékben befolyásolja a mért $\Delta_{47}$ értékeket (STAUDIGEL \& SWART 2016). RitTer et al. (2017) laboratóriumi kísérletei során a rövid ideig $100{ }^{\circ} \mathrm{C}$-ra hevített aragonitminták elveszítették eredeti kapcsolt izotópos összetételüket anélkül, hogy kalcittá alakultak volna.

\section{Karbonátvázú ốsmaradványok}

A kapcsolt izotóp paleotermometria legnagyobb előnye, hogy az eredeti fluidum izotópos összetételének ismerete nélkül is meg lehet határozni a karbonátok kiválási hőmérsékletét. Kalcium-karbonátot kiválasztó élőlények maradványainak vizsgálatával így paleotermometriai rekonstrukció készíthetô, amiből tengeri fossziliák esetében a tengervíz izotópos összetétele is meghatározható a kalcit-víz közötti oxigénizotóp-frakcionáció hômérsékletfüggése révén. Sikerrel vizsgáltak brachiopodákat, kalcit- és aragonitvázú kagylókat, csigákat, belemniteszeket, ammoniteszeket, foraminiferákat és korallokat is.

Recens brachiopodákat vizsgált kapcsolt izotópos módszerrel többek között HeNKES et al. (2013), CAME et al. (2014) és WACKER et al. (2014). Megállapították, hogy a brachiopodák meszes héjain mért $\Delta_{47}$ érték összefüggésben áll a tengervíz átlagos hômérsékletével, és eredményeiket felhasználták kalibrációs görbék meghatározásához. CAME et al. (2007) szilur és karbon időszaki, FinNEgan et al. (2011) ordovíciumi és szilur időszaki, Cummins et al. (2014) szilur időszaki, BRAND et al. (2014) pedig az elmúlt száz évből származó brachiopodákat vizsgált paleohőmérsékleti rekonstrukció céljából. Aragonit-, illetve kalcithéjú kagylókat is felhasználtak a módszer kalibrációjához (EAGLE et al. 2013, HenKes et al. 2013, WACKER et al. 2014). A kagylóhéj $\Delta_{47}$ értékének hômérsékletfüggése alapján CsANK et al. (2011) pliocén kagylókat használt paleohőmérsékleti rekonstrukciójához. PETERSEN et al. (2016b) a K-Pg határon vizsgált kagylókat és a $\Delta_{47}$ értékek által kirajzolt hômérsékleti görbén két csúcsot ismert fel, amelyeket a Dekkánplató vulkanizmusa, illetve a meteoritbecsapódás okozta felmelegedéssel hozott összefüggésbe. GRAUEL et al. (2016) negyedidőszaki csigákat vizsgált sikerrel. PETERSEN et al. (2016c) felsô-kréta csigák és kagylók kapcsolt izotópos vizsgálatával határozta meg a Nyugati-Belsô-tengerág (Western Interior Seaway) tengervíz hőmérsékletét, illetve a tengervíz oxigénizotópos összetételét, majd ezen adatok alapján modellezte a tengervíz sótartalmát. GILBERT et al. (2017) kapcsolt izotópokat használt egy új paleohőmérséklet-rekonstrukciós módszer kifejlesztéséhez. Modern, illetve fosszilis kagylók héjának gyöngyházbevonatát vizs- gálták, és megállapították, hogy a gyöngyházbevonatot alkotó apró aragonittáblák vastagsága összefüggésben áll a kapcsolt izotópos módszerrel meghatározott kristályosodási hômérséklettel. Ezt az összefüggést felhasználva meghatározható a tengervíz hőmérséklete csupán morfológiai információk alapján. Price \& PASSEY (2013) alsó-kréta belemniteszeken mért kapcsolt izotópos hőmérsékletet, DENNIS et al. (2013) pedig felsô-kréta ammoniteszeket, kagylókat és egy belemniteszt vizsgált. Egyes korallfajok esetében a $\Delta_{47}$ értékeket a kalcit biogén kiválasztása során lejátszódó frakciónációs folyamatok befolyásolhatják (GHOSH et al. 2006a, SAENGER et al. 2012). Előfordult, hogy a valódival megegyezó kapcsolt izotópos hômérsékletet mértek recens korallokon (THIAGARAJAN et al. 2011), de a fosszilis fajok esetében ezt nem mindig lehet bizonyítani (SPOONER et al. 2016). KimbALl et al. (2016) megállapította, hogy a recens mélytengeri korallok két csoportja, az aragonit vázú Scleractinia és a kalcitvázú Gorgonia korallok, egymástól eltérő $\Delta_{47}-\mathrm{T}$ összefüggést mutatnak, amire az egyik magyarázat a biogén karbonátkiválasztás során lejátszódó frakcionáció. Foraminiferákat is vizsgáltak, illetve használták fel kalibrációs görbék számításához (TRIPATI et al. 2010, GraUEl et al. 2013, WACKer et al. 2014). Mészvázú nannoplanktonban gazdag üledékek vizsgálatára DRURY \& JoHN (2016) tett kísérletet. A crinoidea vázelemei érzékenyek a diagenetikus hatásokra, mivel magas magnéziumtartalmú kalcitkristályokból állnak és nagy a porozitásuk, ezért nem alkalmasak paleohômérsékleti rekonstrukcióra (SHENTON et al. 2015). Petryshyn et al. (2016) pleisztocén sztromatolitokat vizsgált és vont le tavi vízszintváltozásra vonatkozó következtetéseket.

\section{Kontinentális karbonátok (cseppkövek, édesvízi mészkövek)}

A szárazföldi karbonátok (travertínók, mésztufák, cseppkövek, tavi üledékek) alkalmasak a paleoklíma rekonstrukciójára. Recens édesvízi mészköveket KeLE et al. (2015) vizsgált a kapcsolt izotópos módszer kalibrációja céljából, FALK et al. (2016) pedig ománi hiperalkáli forrásokból kivált recens travertínókon végzett méréseket. A szárazföldi klímarekonstrukció talán legfontosabb karbonátos képződményei azonban a cseppkövek, mivel radiometrikus módszerrel nagy pontossággal korolhatóak, finoman rétegzettek és a kiválási hőmérsékletük becsülhetô a stabilizotópos összetételük alapján. Annak ellenére, hogy vizsgálatuk már az 1960-as években megkezdődött (HENDY \& Wilson 1968, ThOMPSON et al. 1974) a paleoklimatológiai célú cseppkőkutatás jelenleg is virágkorát éri. A cseppkövek esetében azonban a kinetikus (nem-egyensúlyi) frakcionáció megnehezíti a stabil oxigénizotópos összetételen alapuló kiválásihômérséklet-számítást. Az eddig vizsgálatok arra utalnak, hogy a nem-egyensúlyi effektusok a kapcsolt izotópok esetében is érvényesek a cseppkövek (pl. AFFEK et al. 2008, DAËrON et al. 2011) és a barlangi kriogén karbonátok (KLUGE et al. 2014) esetében. Az egyensúlyitól eltérő $\Delta_{47}$ értékeket mértek korallokból (GHOSH et al. 2006a) 
és egyéb biogén karbonátokból (pl. TRIPATI et al. 2010, ThiagarajAn et al. 2011, SAENGER et al. 2012, EAGLE et al. 2013) is. A gyors $\mathrm{CO}_{2}$ kigázosodás következtében előforduló kinetikus frakcionáció nagyobb ${ }^{18} \mathrm{O}$ (és ${ }^{13} \mathrm{C}$ ), de kisebb $\Delta_{47}$ értékekhez vezethet, tehát a $\Delta_{47}$ értékek esetében fennálló nem-egyensúly az oxigén izotópok esetében is nem-egyensúlyi körülményekre utal (AFFEK 2013). Ez az inverz korreláció modern cseppkövek esetében is megfigyelhető (DAËron et al. 2011, WAINER et al. 2011, KLUGE \& AFFEK 2012, KLUGE et al. 2013), amelyek potenciálisan jóval érzékenyebbek a kinetikus izotóphatásokra, mint az oldatban kiváló karbonátok (AFFEK et al. 2008). Az izraeli Soreq-barlang modern cseppköveinek kapcsolt izotópos vizsgálata $8{ }^{\circ} \mathrm{C}$-al nagyobb látszólagos képződési hômérséklet értékeket eredményezett, amit AFFEK et al. (2008) a gyors $\mathrm{CO}_{2}$ kigázosodás következtében előforduló kinetikus

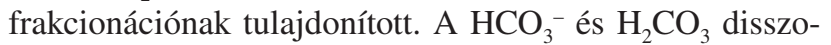
ciációja ugyanis gyorsabban töri fel a ${ }^{12} \mathrm{C}-{ }^{16} \mathrm{O},{ }^{13} \mathrm{O}-{ }^{16} \mathrm{O}$ és ${ }^{12} \mathrm{C}-{ }^{18} \mathrm{O}$ közti kötéseket, mint a ${ }^{13} \mathrm{C}-{ }^{18} \mathrm{O}$ kötést, és emiatt a képződő $\mathrm{CO}_{2} \Delta_{47}$ értéke nagyobb, mint a bikarbonáté, amiből képzôdött (AFFEK et al. 2008). Guo (2008) elméleti számításai alapján a kinetikus hatás változhat, és minden $1 \%$ o növekedés a $\delta^{18} \mathrm{O}$-ban $0,0175-0,029 \%$ o csökkenéssel jár a számolt $\Delta_{47}$ érték esetében. Guo (2008) a kinetikus hatásokat az irreverzibilis dehidratációnak $\left(\mathrm{H}_{2} \mathrm{CO}_{3}\right.$ esetén) és a dehidroxilációnak $\left(\mathrm{HCO}_{3}{ }^{-}\right.$esetén) tulajdonította, amit a $\mathrm{CO}_{2}$ kigázosodása követ.

A gyors $\mathrm{CO}_{2}$ kigázosodás hatásának elkerülésére FAIRCHILD \& BAKER (2012) a víz alatti üledékek $\Delta_{47}$ vizsgálatát javasolta. Különféle barlangi környezetekből származó, aktívan növekedố cseppkövek, sôt, tavacskákban kivált és egyensúlyinak gondolt karbonátok vizsgálata is az egyensúlyinál alacsonyabb $\Delta_{47}$ (és az egyensúlyi $\delta^{18} \mathrm{O}$ értékeknél nagyobb) értékeket eredményezett (DAËron et al. 2011). DAËRON et al. (2011) a tavacskákban kivált karbonátok nem-egyensúlyi $\Delta_{47}$ értékeit a kigázosodás által okozott „memória hatással” magyarázta, ahol a folyamatos kigázosodás növeli a pH-t, ezáltal lassítva az oldott szervetlen szén (DIC - Dissolved Inorganic Carbon) egyensúlyba kerülését. Mindezek következtében a tavacskában (nagyobb pH) történő DIC frakcionáció a barlangi rendszeren belüli korábbi vízkörforgás során történő kigázosodásból származhat. DAËrON et al. (2011) szerint az izotópos egyensúlytól való eltérés mértéke akár egy adott barlangon belül is különbözhet, de korreláció van a $\Delta_{47}$ és a $\delta^{18} \mathrm{O}$ értékek egyensúlytól való eltérésének mértékében. A növekvő csepegési ráta úgy túnik, hogy csökkenti az egyensúlytól való eltérés mértékét (DAËron et al. 2011). A $\Delta_{47}$ értékeket befolyásoló nem-egyensúlyi hatás mértéke egyazon cseppkő esetében is változhat tízezer éves távlatokban, ami akár $10{ }^{\circ} \mathrm{C}$-os eltolódást is eredményezhet a számolt hômérsékletben. WAINER et al. (2011) alapján a minták eltérô kinetikus frakcionációt mutathatnak, aminek számszerú korrekciójához a fluidzárványok $\delta^{18} \mathrm{O}$ értékeit és a modern kalcit minták $\Delta_{47}$ és a $\delta^{18} \mathrm{O}$ értékeinek kombinált használatát javasolta. KLUGE \& AFFeK (2012) és KLUGE et al. (2013) modern cseppköveket vizsgált és a GHOSH et al. (2006a) által meghatározott $\Delta_{47}$ értékektól való eltéréseket a kinetikus frakcionáció mértékének, valamint a csepegővíz $\delta^{18} \mathrm{O}$ értékének meghatározására használta. Cseppkövek esetében az egyensúlyi $\Delta_{47}$ értékektől való eltérések változása alkalmas a kinetikus frakcionáció időbeni változásának meghatározására azokban az esetekben, amikor a cseppkő növekedési hômérséklete viszonylag állandó, vagy egyéb módon meghatározható (KLUGE \& AFFEK 2012). MECKLER et al. (2015) két modern cseppkövet, valamint a MIS 12-9 közötti idôszakból származó idősebb cseppköveket vizsgált Észak-Borneóból. Elsőként alkalmaztak együttesen négy különféle módszert (fluidzárvány homogenizációs hőmérséklet, fluidzárvány víz nemesgáz-koncentrációja, fluidzárvány víz és kalcit közötti oxigénizotópfrakcionáció, kapcsolt-izotópok) a képződési hőmérséklet meghatározása, illetve a módszerek használhatóságának tesztelése céljából és a különböző módszerek által rekonstruált hőmérsékleti értékek a legtöbb esetben a hibahatáron belül egyeztek.

A kinetikus frakcionáció izotópos értékekre gyakorolt hatásának tanulmányozására és a stabil- és kapcsolt izotópos termométerek kalibrációjára a laboratóriumi kísérletek kiválóan alkalmasak. AFFeK \& ZAARUR (2014) kísérletei során az oldat felszínén kiváló, valamint mélyen az oldatban kiváló karbonát stabil- és kapcsolt izotópos értékének vizsgálatával próbálta modellezni a cseppkövek képződését kísérô nem-egyensúlyi folyamatokat. Az oldatok felszínén kiváló karbonátok izotópos értékeit a felszíni $\mathrm{CO}_{2}$ kigázosodás nagyobb mértékben befolyásolja, mint az oldatban történő kiválás (kisebb kiválási sebesség) esetében és mindezek következtében a mért $\delta^{18} \mathrm{O}$ értékek nagyobbak, a $\Delta_{47}$ értékek pedig kisebbek, mint az elfogadott kalibrációs egyenesek (AFFEK \& ZAARUR 2014). Mindezek következtében az oldatban kiváló karbonátok egyensúlyi körülményeket tükrözhetnek, míg az oldat felszínén kiváló karbonátok esetében a kinetikus folyamatok (egyirányú $\mathrm{CO}_{2}$ kigázosodás) hatásai felerósítve jelennek meg a $\delta^{18} \mathrm{O}$ és $\Delta_{47}$ értékekben, ami alapján utóbbiak a cseppkőképződés analógiájának tekinthetóek. AFFEK \& ZAARUR (2014) szerint a különféle barlangok recens karbonátkiválásai a fenti két, az oldat felszínén, illetve az oldatban kivált karbonátok alapján létrehozott kalibrációs egyenes között helyezkednek el. AfFeK et al. (2014) az izraeli Soreq-barlang recens és késóholocén képződményeinek vizsgálata során mindkét említett kalibrációt tesztelve arra jutott, hogy a Soreq-barlang cseppkövei a két kalibráció közé, egy barlang-specifikus kalibrációs egyenesre esnek (mid-point calibration, Fig. 5B in: AfFEK et al. 2014). Ez egyben azt is jelenti, hogy az oldat felszínén kiváló karbonátok alapján készült kalibráció nem alkalmas a Soreq-barlang cseppköveinek pontos modellezésére, ami feltehetôen annak köszönhetô, hogy az egyensúlytól való eltérés mértéke egyéb, hőmérsékleten kívüli paraméterektôl (pl. az oldat karbonáttelítettsége) is függhet (AFFEK et al. 2014).

AFFEK et al. (2014) szerint elképzelhető, hogy TREMAINE et al. (2011) cseppkövekre érvényes kalcit-víz oxigénizotópfrakcionációs görbéjéhez hasonlóan egy barlangi adatokon 
alapuló T- $\Delta_{47}$ kalibráció is létrehozható. Ez azonban egyelőre még a jövő kérdése, ugyanis jelenleg kevés barlangból mindössze néhány $\Delta_{47}$ adat áll rendelkezésre, és főként az alacsony hőmérsékletû adatok hiányoznak a $\Delta_{47}$ termométer cseppkövekre érvényes kalibrációjához. A fenti rövid összefoglaló alapján elmondható, hogy a kapcsolt izotópos módszer cseppköveken történő alkalmazása még korántsem tekinthető kiforrottnak, mivel a cseppkőképződést kísérő kinetikus frakcionáció megnehezíti a paleoklimatológiai következtetések levonását. A módszer cseppkövekre történő kalibrációjához tehát további vizsgálatok szükségesek és csak ezt követően kerülhet sor a rutinszerú alkalmazásra.

\section{Bioapatit és fluorapatit}

A kapcsolt izotópos vizsgálatok apatitásványok kiválási hőmérsékletének meghatározására is alkalmasak. Az apatit $\left(\mathrm{Ca}_{10}\left(\mathrm{PO}_{4}, \mathrm{CO}_{3}\right)_{6}(\mathrm{~F}, \mathrm{OH})_{2}\right)$ szerkezetében a foszfát- $\left(\mathrm{PO}_{4}{ }^{3-}\right)$ csoportot részben karbonátcsoport $\left(\mathrm{CO}_{3}{ }^{2-}\right)$ helyettesítheti, így a mintából tömény foszforsavas reakció során széndioxid gáz fejleszthetô, aminek a $\Delta_{47}$ értéke a vizsgált ásvány $\Delta_{47}$ értékétől függ. A módszerrel meg lehet határozni a fogzománcot, a dentint és a csontokat nagyrészt felépítő biogén hidroxiapatit $\left(\mathrm{Ca}_{10}\left(\mathrm{PO}_{4}, \mathrm{CO}_{3}\right)_{6}(\mathrm{OH})_{2}\right)$ kristályosodási hőmérsékletét (EAGLE et al. 2010, 2011; SUAREZ \& PASSEY 2014), valamint a fluorapatitot $\left(\mathrm{Ca}_{10}\left(\mathrm{PO}_{4}, \mathrm{CO}_{3}\right)_{6} \mathrm{~F}_{2}\right)$ vizsgálva lehetôség nyílik a foszforitokat ért diagenetikus folyamatok tanulmányozására (BRADBURY et al. 2015, STOLPER \& EILER 2016). Az apatiton végzett vizsgálatokat a már publikált eredmények ellenére sem lehet még kiforrottnak nevezni. EAGLE et al. (2010, 2011) és SuAREZ \& PASSEY (2014) kutatásai során a GHOSH et al. (2006a) által kalcitra meghatározott kalibrációt használta bioapatit mintákra is. Ez azonban téves értelmezésre adhat okot, ezért indokolt egy bioapatitra vonatkozó kalibráció használata (WACKER et al. 2016). A bioapatiton folytatott kapcsolt izotópos kutatások a már kihalt gerincesek (dinoszauruszok, cápák, emlősök) testhőmérsékletének a rekonstrukciójával foglalkoznak. Olyan kérdésekre kaphatunk választ segítségükkel, hogy például képesek voltak-e a dinoszauruszok a testhőmérsékletüket szabályozni (EAGLE et al. 2011). Érdemes megemlíteni, hogy a fogakon, csontokon végzett mérések eredményeit újabban dinoszaurusz tojásokon végzett vizsgálatokkal próbálják alátámasztani (EAGLE et al. 2015, CANAVAN et al. 2016).

\section{Talajkarbonátok, sziderites talajok, kalcitcementek}

A talajkarbonátok a talajosodás során képződő szerves, vagy szervetlen eredetú, másodlagos kalcitkiválások. A pedogén karbonátok képződési hőmérsékletének meghatározása az oxigénizotópos vizsgálatokkal bizonytalan, mert a talajnedvesség izotópos összetételét több nehezen mérhető vagy becsülhető tényező (pl. csapadék izotópos összetétele, párolgás frakcionáló hatása, elsődleges karbonátok befolyásoló szerepe, C3-C4 típusú növények aránya) befolyásolja. Mivel a mért $\Delta_{47}$ értékek ezektől a paraméterektől függetlenek, a karbonátok képződési hőmérsékletét, illetve abból visszaszámolva a talajnedvesség $\delta^{18} \mathrm{O}$ értékét is meg lehet határozni (GHOsh et al. 2006b, Huntington \& LECHLER 2015, RinGHAM et al. 2016). Mindez azért fontos, mert a talajkarbonátok kristályosodási hőmérsékletéből és a talajfluidumok izotópos összetételéból paleotopográfiai és paleoklimatológiai következtetéseket lehet levonni.

Recens minták vizsgálata alapján a talajkarbonátok képződési hômérséklete meghaladja a mintázott terület átlagos éves lég- és talajhőmérsékletét, és képződésük a nyári időszakra jellemző (pl. QUADE et al. 2007, 2013, PASSEY et al. 2010; Hough et al. 2014; GALlAGHER \& SHELdON 2016). Az évszakos változáson kívül a növényzetnek (RINGHAM et al. 2016) és a tengerszint feletti magasságnak (PETERs et al. 2013, Hough et al. 2014, BurgenER et al. 2016) a talajkarbonátok $\Delta_{47}$ értékére gyakorolt hatását is vizsgálták. Geológiai időskálán történő alkalmazásra példa a délamerikai Altiplano (GHOSH et al. 2006b, KAR et al. 2016), az Andok (GARZIONE et al. 2008) kiemelkedésének, vagy Nevada késő-kréta topográfiai fejlődésének (SNELL et al. 2014) vizsgálata. METHNER et al. (2016) paleotalajok geokémiai vizsgálatával elsőként tudta kimutatni a középsô-eocén hőmérsékleti optimumot szárazföldi rétegsorban.

A talajkarbonátokhoz hasonlóan kalcitcementek is használhatóak kapcsolt izotópos paleohőmérsékleti és paleotopográfiai rekonstrukcióhoz. Ilyen irányú vizsgálatokat FAN et al. (2014) végzett a Sziklás-hegységből származó devon idôszaki homokkövek karbonátcementjein. DEFLIESE \& LOHMANN (2016) meteorikus freatikus kalcitcementeken alapuló kapcsolt izotópos paleohőmérsékleti rekonstrukció lehetôségeit tárta fel. Nedves klímájú kontinentális területeken, ahol pedogén kalcit nem tud képződni, a sziderites $\left(\mathrm{FeCO}_{3}\right)$ talajokat lehet használni paleohőmérsékleti rekonstrukciókhoz (FERNANDEZ et al. 2014, 2016). A sziderit anyagú minták vizsgálatának szélesebb körú alkalmazásához elengedhetetlen a sziderit kapcsolt izotópos hőmérsékleti kalibrációjának pontosítása (FERNANDEZ et al. 2014, vAN DiJK et al. 2016).

\section{Diagenetikus fejlődéstörténet rekonstrukciója (kalcit, dolomit, magnezit)}

Átkristályosodott kalciton kapcsolt izotópos méréseket végezve a vizsgált kőzet diagenetikus fejlődéstörténetére lehet következtetéseket levonni (HunTINGTON et al. 2011, BERGMAN et al. 2013, BuDd et al. 2013, LloYd et al. 2017, SAMPLE et al. 2017). Meghatározható a diagenetikus folyamatok során kivált cementek kristályosodási hőmérséklete, az átkristályosodás hőmérséklete, illetve ezekből az eredeti fluidum oxigén-izotópos összetételét is vissza lehet számolni (DALE et al. 2014, RitTER et al. 2015). Karbonátos konkréciók vizsgálatával DALE et al. (2014), illetve HEIMHOFER et al. (2017) kréta időszaki palák diagenezistörténetét tudta rekonstruálni.

Nem csak tiszta kalcium-karbonát, hanem részben dolomitosodott kalcit, illetve tiszta dolomit is vizsgálható 
kapcsolt izotópokkal. Átdolomitosodott karbonátokat (FERry et al. 2011, SENA et al. 2014, LoYd et al. 2015, MiLlán et al. 2016), vagy a diagenetikus fluidumokból kivált dolomitot (BRISTOW et al. 2011, VANDEGINSTE et al. 2014) vizsgálva a diagenetikus fejlődéstörténetre lehet következtetéseket levonni, míg földfelszíni körülmények között kivált, elsődleges dolomitokból paleohőmérsékleti rekonstrukció készíthető (VANDEVELDE et al. 2013, DALE et al. 2014). Viszonylag kevés tanulmány foglalkozott a mélyen eltemetett karbonátos rezervoárokkal, mivel a hőmérsékleti kalibrációk eddig a $100{ }^{\circ} \mathrm{C}$ alatti hőmérsékleti tartományra korlátozódtak. MACDoNALD et al. (2015) dolomitos szénhidrogén-rezervoárok dolomitosodásának hőmérsékleti körülményeit rekonstruálta sikerrel $\Delta_{47}$ értékek alapján. Kapcsolt izotóp termometria (és egyéb módszerek) segítségével MiLlán et al. (2016) három dolomitfázist különített el devon időszaki karbonátokban, és meghatározta a hozzájuk köthető diagenetikus környezetet. VANDEVELDE et al. (2013) dolomitos paleotalajokból készített őskörnyezeti rekonstrukciót a paleocén-eocén határon. CAME et al. (2017) dolomitok vizsgálata során a kapcsolt izotóp- és folyadékzárvány-termometria együttes használatára tett javaslatot.

WiNKELSTERN et al. (2016) munkájában kiemeli, hogy az azonos hőmérsékleten kivált kalcitok és dolomitok $\Delta_{47}$ értékei egymás hibahatárain belülre esnek, így a kalcitokra készített kalibrációs görbék használhatóak a dolomit mintákon. MiLLÁN et al. (2016) munkájában például KELE et al. (2015) édesvízi mészköveken alapuló kalibrációját alkalmazta dolomitokra. A számolt hőmérsékletek jó egyezést mutattak a konvencionális oxigénizotópos módszer és a fluidzárvány homogenizációs módszerek eredményeivel, ami alapján MiLlÁN et al. (2016) azt a következtetést vonta le, hogy az édesvízi mészköveken alapuló kalibráció magasabb hőmérsékleti tartományokra is kiterjeszthető.

Magnezit vizsgálatával az ultrabázisos kőzetek átalakulási folyamataiba nyerhetünk betekintést (STREIT et al. 2012, FALK \& KELEMEN 2015, DEL REAL et al. 2016).

\section{Szerkezetföldtani alkalmazások}

Karbonátkiválások vizsgálatával meghatározható a törések és a vetők mentén mozgó fluidumok hőmérséklete, illetve a fluidum eredeti oxigénizotópos-összetétele (SWANSOn et al. 2012, BERGMAN et al. 2013, LoYD et al. 2013, CRUSET et al. 2016, QueSNEL et al. 2016). A töréskitöltő karbonátok $\Delta_{47}$ értékei geotermális rezervoárok hőmérsékletének meghatározására is használhatóak (SUMNER et al. 2015). LuETKEMEYER et al. (2016) például a Szent Andrástörésvonal deformációs zónái közötti paleofluidum-áramlást rekonstruálta segítségükkel. Kapcsolt izotópos méréseket is alkalmazva HoDSON et al. (2016) csoportosítani tudta az általa vizsgált karbonátcement generációit eredetük szerint, és azokat különböző szerkezeti deformációs eseményekhez tudta kötni. SimAN-Tov et al. (2016) vető- tükrök karbonátjait vizsgálta, és vont le következtetéseket a kapcsolt izotópok újrarendeződésének dinamikájáról, kiemelve, hogy a kapcsolt izotópok fontos szerepet tölthetnek be szeizmikus események terepi jelzőjeként. A szeizmikus események, csúszások során ugyanis gyors felmelegedés történhet, amit gyors lehúlés követhet és ezek a folyamatok az izotópos kapcsolatokat, így a karbonátok $\Delta_{47}$ értékét is befolyásolják.

\section{Meteoritok}

Mindezidáig összesen két tanulmány foglalkozott meteoritok kapcsolt izotópos vizsgálatával, aminek oka, többek között, a rendelkezésre álló karbonát kis mennyisége. GUO \& EILER (2007) CM kondritok, a naprendszer kialakulásának első tíz millió évében lezajlott vizes átalakulási hőmérsékletét állapította meg. HALEVY et al. (2011) egy marsi eredetú meteoritot vizsgált, ami a marsi kéreg legidősebb ismert maradványa és a módszer segítségével meghatározta, hogy a meteorit másodlagos karbonátásványai $18{ }^{\circ} \mathrm{C}$ körüli hőmérsékleten váltak ki a Mars felszínén, körülbelül 4 milliárd évvel ezelőtt.

\section{Kapcsolt izotópok egyéb $\left(\mathrm{CH}_{4}, \mathrm{O}_{2}, \mathrm{~N}_{2}\right)$ gázokban}

Bár a kapcsolt izotópos kutatások fő iránya a karbonátokból fejlesztett szén-dioxid gáz vizsgálata az eredeti karbonát kristályosodási hőmérsékletének a meghatározása céljából, a szén-dioxidon kívül más gázokban (pl. metán, oxigén, nitrogén) is végbemennek a nehéz izotópok közötti kötések létrejöttét elősegítő folyamatok (WANG et al. 2004, YEUNG 2016).

Nehéz izotópokkal többszörösen helyettesített metánt $\left({ }^{13} \mathrm{CH}_{3} \mathrm{D}\right.$ és ${ }^{12} \mathrm{CH}_{2} \mathrm{D}_{2}$ ) vizsgálva meghatározható a képződési hőmérséklet (TsuJi et al. 2012, ONO et al. 2014, LIU \& LiU 2016, PiASECKI et al. 2016). A metán kapcsolt izotópos összetételét a $\Delta_{18}$ értékkel szokás kifejezni, ami azt mutatja meg, hogy a 18-as tömegszámú $\mathrm{CH}_{4}$ molekulák mennyire dúsulnak a mintában a sztochasztikus, véletlenszerú eloszláshoz képest (STOLPER et al. 2014a). A metán képződési hőmérséklete alapján meghatározható az eredete. Megállapítható továbbá az is, hogy a gáz biológiai, vagy geológiai folyamatok során jött-e létre (STOLPER et al. 2014a, b, 2015; INAGAKI et al. 2015; Douglas et al. 2016; WANG et al. 2016). INAGAKI et al. (2015) többek között kapcsolt izotópos vizsgálatokkal mutatott rá arra, hogy biogén metánképződés zajlik 1,5-2 km-rel a tenger felszíne alatt eltemetett lignitrétegekben, $40-60{ }^{\circ} \mathrm{C}$ hőmérsékleten. Az összetettebb szerves molekulák (pl. etán) kapcsolt izotópos vizsgálatának irányába WEBB et al. (2017) elméleti számításai jelentik az első lépést.

A többszörösen nehéz izotópokkal helyettesített oxigén $\left({ }^{18} \mathrm{O}-{ }^{18} \mathrm{O}\right.$ és $\left.{ }^{17} \mathrm{O} \_{ }^{18} \mathrm{O}\right)$ és nitrogén $\left({ }^{15} \mathrm{~N}-{ }^{15} \mathrm{~N}\right)$ molekulák dúsulásának mértéke ( $\operatorname{sorban} \Delta_{36}, \Delta_{35}$ és $\Delta_{30}$ ) a véletlenszerú eloszláshoz képest pedig az atmoszféra állapotáról, illetve biológiai folyamatokról hordozhat információt (YEUNG et al. 2012, 2014, 2015; YEUNG 2016; Li et al. 2016). 


\section{Összefoglalás}

Cikkünk elsődleges célja, hogy felhívja a figyelmet a kapcsolt izotóp-geokémia (clumped isotope geochemistry), egy nemrégiben született új tudományos módszer létezésére, és segítséget nyújtson a módszer alapjainak megértésében. A módszer jelenleg is gyors fejlődésen megy keresztül, ami a múszerek folyamatos fejlesztése révén már egyre kisebb mintamennyiségekből is lehetővé teszi a mérést. Egymást követik a különböző hőmérsékleti kalibrációk, amelyek használata azonban még óvatosságot igényel. A röviden bemutatott főbb alkalmazási területek bôvebb megismeréséhez a hivatkozott irodalmak nyújthatnak további információkat. Az olvasó reményeink szerint kedvet kap majd a módszer alkalmazásához is, ami hozzájárulhat a hazai geokémiai kutatások nemzetközi versenyképességé- nek növeléséhez, valamint olyan új kutatási eredményekhez, amelyek segítségével számos új, eddig nem látható információt nyerhetünk ki hazai és külföldi geológiai képződményekből.

\section{Köszönetnyilvánítás}

Köszönet illeti Palcsu Lászlót, DuLAI Alfrédot, VETő Istvánt és a kézirat lektorait, PoROs Zsófiát és BÁLDI Katalint, hogy hasznos megjegyzéseikkel hozzájárultak a kézirat színvonalának növeléséhez. KELE Sándort a SCIEX posztdoktori ösztöndíjprogramja (ClumpIT, No. 13.071-2, ETH Zürich) és az MTA Bolyai János kutatási ösztöndíja támogatta. BAJNAI Dávid az Európai Unió Horizon 2020 kutatási és innovációs programjának (BASE-LiNE Earth, No. 643084) támogatásában részesült.

\section{Irodalom - References}

AFFEK, H. P. 2013: Clumped isotopic equilibrium and the rate of isotope exchange between $\mathrm{CO}_{2}$ and water. - American Journal of Science 313/4, 309-325. https://doi.org/10.2475/04.2013.02

AfFEK, H. P. \& ZAARUR, S. 2014: Kinetic isotope effect in $\mathrm{CO}_{2}$ degassing: Insight from clumped and oxygen isotopes in laboratory precipitation experiments. — Geochimica et Cosmochimica Acta 143, 319-330. https://doi.org/10.1016/j.gca.2014.08.005

Affek, H. P., Bar-Matthews, M., Ayalon, A., Matthews, A. \& EILER, J. M. 2008: Glacial/interglacial temperature variations in Soreq cave speleothems as recorded by 'clumped isotope' thermometry. — Geochimica et Cosmochimica Acta 72/22, 5351-5360. https://doi.org/10.1016/j.gca.2008.06.031

Bergman, S. C., Huntington, K. W. \& Crider, J. G. 2013: Tracing paleofluid sources using clumped isotope thermometry of diagenetic cements along the Moab Fault, Utah. — American Journal of Science 313/5, 490-515. https://doi.org/10.2475/05.2013.03

Bernasconi, S. M., Hu, B., Wacker, U., Fiebig, J., Breitenbach, S. F. \& RutZ, T. 2013: Background effects on Faraday collectors in gassource mass spectrometry and implications for clumped isotope measurements. - Rapid Communications in Mass Spectrometry 27/5, 603-612. https://doi.org/10.1002/rcm.6490

BigELEISEN, J. 1955: Statistical Mechanics of Isotopic Systems with Small Quantum Corrections. I. General Considerations and the Rule of the Geometric Mean. — The Journal of Chemical Physics 23/12, 2264-2267. https://doi.org/10.1063/1.1740735

BIGELEISEN, J. 1965: Chemistry of Isotopes - Isotope chemistry has opened new areas of chemical physics, geochemistry, and molecular biology. - Science 147/3657, 463-471. https://doi.org/10.1126/science.147.3657.463

Bigeleisen, J. \& MAYER, M. G. 1947: Calculation of equilibrium constants for isotopic exchange reactions. - Journal of Chemical Physics 15/5, 261-267. https://doi.org/10.1063/1.1746492

Bonifacie, M., Calmels, D., Eiler, J. M., Horita, J., Chaduteau, C., Vasconcelos, C., Agrinier, P., Katz, A., Passey, B. H., Ferry, J. M. \& BourRAND, J.-J. 2017: Calibration of the dolomite clumped isotope thermometer from 25 to $350{ }^{\circ} \mathrm{C}$, and implications for a universal calibration for all $(\mathrm{Ca}, \mathrm{Mg}, \mathrm{Fe}) \mathrm{CO}_{3}$ carbonates. - Geochimica et Cosmochimica Acta 200, 255-279. https://doi.org/ 10.1016/j.gca.2016.11.028

Bradbury, H. J., VAnDEginste, V. \& John, C. M. 2015: Diagenesis of phosphatic hardgrounds in the Monterey Formation: A perspective from bulk and clumped isotope geochemistry. — Geological Society of America Bulletin 127/9-10, 1453-1463. https://doi.org/ 10.1130/b31160.1

Brand, U., CAme, R. E., AfFeK, H., Azmy, K., Mooi, R. \& LAYton, K. 2014: Climate-forced change in Hudson Bay seawater composition and temperature, Arctic Canada. — Chemical Geology 388, 78-86. https://doi.org/10.1016/j.chemgeo.2014.08.028

Bristow, T. F., Bonifacie, M., Derkowski, A., EILER, J. M. \& GrotZinger, J. P. 2011: A hydrothermal origin for isotopically anomalous cap dolostone cements from south China. — Nature 474/7349, 68-71. https://doi.org/10.1038/nature10096

Budd, D. A., Frost, E. L., Huntington, K. W. \& AllwardT, P. F. 2013: Syndepositional Deformation Features in High-Relief Carbonate Platforms: Long-Lived Conduits for Diagenetic Fluids. — Journal of Sedimentary Research 83/1, 12-36. https://doi.org/10.2110/ jsr.2013.3

Burgener, L., Huntington, K. W., Hoke, G. D., Schauer, A., Ringham, M. C., Latorre, C. \& Díaz, F. P. 2016: Variations in soil carbonate formation and seasonal bias over $>4 \mathrm{~km}$ of relief in the western Andes $\left(30^{\circ} \mathrm{S}\right)$ revealed by clumped isotope thermometry. — Earth and Planetary Science Letters 441, 188-199. https://doi.org/10.1016/j.epsl.2016.02.033

Came, R. E., Eiler, J. M., Veizer, J., Azmy, K., Brand, U. \& Weidman, C. R. 2007: Coupling of surface temperatures and atmospheric $\mathrm{CO}_{2}$ concentrations during the Palaeozoic era. — Nature 449/7159, 198-201. https://doi.org/10.1038/nature06085

CAme, R. E., BRAnd, U. \& AFFEK, H. P. 2014: Clumped isotope signatures in modern brachiopod carbonate. — Chemical Geology 377, 20-30. https://doi.org/10.1016/j.chemgeo.2014.04.004 
Came, R. E., Azmy, K., Tripati, A. \& Olanipekun, B.-J. 2017: Comparison of clumped isotope signatures of dolomite cements to fluid inclusion thermometry in the temperature range of $73-176^{\circ} \mathrm{C}$. - Geochimica et Cosmochimica Acta 199, 31-47. https://doi.org/ 10.1016/j.gca.2016.10.028

Canavan, R. R., Field, D. J., Zelenitsky, D. K., Therrien, F. O. \& Affek, H. P. 2016: Eggshell clumped isotope temperatures: implications for dinosaur thermoregulation. - 5th International Clumped Isotope Workshop, St. Petersburg, Florida, p. 6.

CAO, X. \& LiU, Y. 2012: Theoretical estimation of the equilibrium distribution of clumped isotopes in nature. - Geochimica et Cosmochimica Acta 77, 292-303. https://doi.org/10.1016/j.gca.2011.11.021

Cruset, D., Cantarero, I., Travé, A., Vergés, J. \& John, C. M. 2016: Crestal graben fluid evolution during growth of the Puig-reig anticline (South Pyrenean fold and thrust belt). — Journal of Geodynamics 101, 30-50. https://doi.org/10.1016/j.jog.2016.05.004

Csank, A. Z., Tripati, A. K., Patterson, W. P., Eagle, R. A., Rybczynski, N., Ballantyne, A. P. \& Eiler, J. M. 2011: Estimates of Arctic land surface temperatures during the early Pliocene from two novel proxies. - Earth and Planetary Science Letters 304/3-4, 291-299. https://doi.org/10.1016/j.eps1.2011.02.030

CUI, L. \& WANG, X. 2014: Determination of clumped isotopes in carbonate using isotope ratio mass spectrometer: Effects of extraction potential and long-term stability. - International Journal of Mass Spectrometry 372, 46-50. https://doi.org/10.1016/ j.ijms.2014.08.006

Cummins, R. C., Finnegan, S., Fike, D. A., Eiler, J. M. \& Fischer, W. W. 2014: Carbonate clumped isotope constraints on Silurian ocean temperature and seawater $\delta^{8} \mathrm{O}$. — Geochimica et Cosmochimica Acta 140, 241-258. https://doi.org/10.1016/j.gca.2014.05.024

Daëron, M., Guo, W., Eiler, J., Genty, D., Blamart, D., Boch, R., Drysdale, R., Maire, R., Wainer, K. \& ZanchetTa, G. $2011:{ }^{13} \mathrm{C}^{18} \mathrm{O}$ clumping in speleothems: Observations from natural caves and precipitation experiments. - Geochimica et Cosmochimica Acta 75/12, 3303-3317. https://doi.org/10.1016/j.gca.2010.10.032

DaËron, M., Blamart, D., Peral, M. \& AfFeK, H. P. 2016: Absolute isotopic abundance ratios and the accuracy of $\Delta_{47}$ measurements. - Chemical Geology 442, 83-96. https://doi.org/10.1016/j.chemgeo.2016.08.014

Dale, A., John, C. M., Mozley, P. S., Smalley, P. C. \& Muggeridge, A. H. 2014: Time-capsule concretions: Unlocking burial diagenetic processes in the Mancos Shale using carbonate clumped isotopes. - Earth and Planetary Science Letters 394, 30-37. https://doi.org/10.1016/j.epsl.2014.03.004

Defliese, W. F., Hren, M. T. \& Lohmann, K. C. 2015: Compositional and temperature effects of phosphoric acid fractionation on $\Delta_{47}$ analysis and implications for discrepant calibrations. - Chemical Geology 396, 51-60. https://doi.org/10.1016/j.chemgeo. 2014.12.018

Defliese, W. F. \& Lohmann, K. C. 2016: Evaluation of meteoric calcite cements as a proxy material for mass-47 clumped isotope thermometry. — Geochimica et Cosmochimica Acta 173, 126-141. https://doi.org/10.1016/j.gca.2015.10.022

Del Real, P. G., Maher, K., Kluge, T., Bird, D. K., Brown, G. E. \& John, C. M. 2016: Clumped-isotope thermometry of magnesium carbonates in ultramafic rocks. — Geochimica et Cosmochimica Acta 193, 222-250. https://doi.org/10.1016/j.gca.2016.08.003

DENNIS, K. J. \& SCHRAG, D. P. 2010: Clumped isotope thermometry of carbonatites as an indicator of diagenetic alteration. — Geochimica et Cosmochimica Acta 74/14, 4110-4122. https://doi.org/10.1016/j.gca.2010.04.005

Dennis, K. J., AfFeK, H. P., PAssey, B. H., Schrag, D. P. \& EILER, J. M. 2011: Defining an absolute reference frame for 'clumped' isotope studies of $\mathrm{CO}_{2}$. - Geochimica et Cosmochimica Acta 75/22, 7117-7131. https://doi.org/10.1016/j.gca.2011.09.025

Dennis, K. J., Cochran, J. K., Landman, N. H. \& SchraG, D. P. 2013: The climate of the Late Cretaceous: New insights from the application of the carbonate clumped isotope thermometer to Western Interior Seaway macrofossil. — Earth and Planetary Science Letters 362, 51-65. https://doi.org/10.1016/j.eps1.2012.11.036

Douglas, P. M. J., Stolper, D. A., Smith, D. A., Walter Anthony, K. M., Paull, C. K., Dallimore, S., Wik, M., Crill, P. M., Winterdahl, M., Eiler, J. M. \& Sessions, A. L. 2016: Diverse origins of Arctic and Subarctic methane point source emissions identified with multiply-substituted isotopologues. — Geochimica et Cosmochimica Acta 188, 163-188. https://doi.org/10.1016/ j.gca.2016.05.031

DRURY, A. J. \& JOHN, C. M. 2016: Exploring the potential of clumped isotope thermometry on coccolith-rich sediments as a sea surface temperature proxy. — Geochemistry, Geophysics, Geosystems 17/10, 4092-4104. https://doi.org/10.1002/2016gc006459

Eagle, R. A., Schauble, E. A., Tripati, A. K., Tutken, T., Hulbert, R. C. \& Eiler, J. M. 2010: Body temperatures of modern and extinct vertebrates from ${ }^{13} \mathrm{C}-{ }^{18} \mathrm{O}$ bond abundances in bioapatite. - Proceedings of the National Academy of Sciences of the United States of America 107/23, 10377-10382. https://doi.org/10.1073/pnas.0911115107

Eagle, R. A., Tütken, T., Martin, T. S., Tripati, A. K., Fricke, H. C., Connely, M., Cifelli, R. L. \& Eiler, J. M. 2011: Dinosaur body temperatures determined from isotopic $\left({ }^{13} \mathrm{C}-{ }^{18} \mathrm{O}\right)$ ordering in fossil biominerals. - Science 333/6041, 443-445. https://doi.org/ 10.1126/science. 1206196

Eagle, R. A., Eiler, J. M., Tripati, A. K., Ries, J. B., Freitas, P. S., Hiebenthal, C., Wanamaker, A. D., Taviani, M., Elliot, M., Marenssi, S., NAKAmURa, K., RamireZ, P. \& Roy, K. 2013: The influence of temperature and seawater carbonate saturation state on ${ }^{13} \mathrm{C}-{ }^{18} \mathrm{O}$ bond ordering in bivalve mollusks. — Biogeosciences 10/7, 4591-4606. https://doi.org/10.5194/bg-10-4591-2013

Eagle, R. A., Enriquez, M., Grellet-Tinner, G., Perez-Huerta, A., Hu, D., Tutken, T., Montanari, S., Loyd, S. J., Ramirez, P., Tripati, A. K., Kohn, M. J., Cerling, T. E., Chiappe, L. M. \& Eiler, J. M. 2015: Isotopic ordering in eggshells reflects body temperatures and suggests differing thermophysiology in two Cretaceous dinosaurs. — Nature Communications 6/8296, 1-11. https://doi.org/10.1038/ncomms9296

EILER, J. M. 2007: "Clumped-isotope" geochemistry—The study of naturally-occurring, multiply-substituted isotopologues. — Earth and Planetary Science Letters 262/3-4, 309-327. https://doi.org/10.1016/j.eps1.2007.08.020

EILer, J. M. \& Schauble, E. 2004: ${ }^{18} \mathrm{O}^{13} \mathrm{C}^{16} \mathrm{O}$ in Earth's atmosphere. — Geochimica et Cosmochimica Acta 68/23, $4767-4777$. https://doi.org/10.1016/j.gca.2004.05.035 
Epstein, S., Buchsbaum, R., Lowenstam, H. \& Urey, H. C. 1951: Carbonate-water isotopic temperature scale. — Geological Society of America Bulletin 62/4, 417-426. https://doi.org/10.1130/0016-7606

Epstein, S., Buchsbaum, R., Lowenstam, H. A. \& UREY, H. C. 1953: Revised carbonate-water isotopic temperature scale. — Geological Society of America Bulletin 64/11, 1315-1326. https://doi.org/10.1130/0016-7606(1953)64[1315:rcits]2.0.co;2

FAIRChILD, I. J. \& BAKER, A. 2012: Speleothem Science: From Process to Past Environments. — Wiley-Blackwell, Chichester, UK, pp. 450. https://doi.org/10.1002/9781444361094

FALK, E. S. \& KelEMEN, P. B. 2015: Geochemistry and petrology of listvenite in the Samail ophiolite, Sultanate of Oman: Complete carbonation of peridotite during ophiolite emplacement. — Geochimica et Cosmochimica Acta 160, 70-90. https://doi.org/ 10.1016/j.gca.2015.03.014

Falk, E. S., Guo, W., Paukert, A. N., Matter, J. M., Mervine, E. M. \& Kelemen, P. B. 2016: Controls on the stable isotope compositions of travertine from hyperalkaline springs in Oman: Insights from clumped isotope measurements. — Geochimica et Cosmochimica Acta 192, 1-28. https://doi.org/10.1016/j.gca.2016.06.026

Fan, M., Hough, B. G. \& PAssey, B. H. 2014: Middle to late Cenozoic cooling and high topography in the central Rocky Mountains: Constraints from clumped isotope geochemistry. — Earth and Planetary Science Letters 408, 35-47. https://doi.org/10.1016/ j.eps1.2014.09.050

Fernandez, A., TAng, J. \& Rosenheim, B. E. 2014: Siderite 'clumped' isotope thermometry: A new paleoclimate proxy for humid continental environments. — Geochimica et Cosmochimica Acta 126, 411-421. https://doi.org/10.1016/j.gca.2013.11.006

Fernandez, A., van DijK, J., MüLler, I. A. \& Bernasconi, S. M. 2016: Early Eocene latitudinal temperature gradient estimated from siderite clumped isotope thermometry. — 5th International Clumped Isotope Workshop, St. Petersburg, Florida, 19 p.

Ferry, J. M., PASSEY, B. H., VASCONCElos, C. \& Eiler, J. M. 2011: Formation of dolomite at $40-80{ }^{\circ}$ C in the Latemar carbonate buildup, Dolomites, Italy, from clumped isotope thermometry. — Geology 39/6, 571-574. https://doi.org/10.1130/g31845.1

Fiebig, J., Hofmann, S., NikLAS, L., LÜDECKE, T., MethNER, K. \& WACKER, U. 2016: Slight pressure imbalances can affect accuracy and precision of dual inlet-based clumped isotope analysis. - Isotopes in Environmental and Health Studies 52/1-2, 12-28. https://doi.org/10.1080/10256016.2015.1010531

Finnegan, S., Bergmann, K., Eiler, J. M., Jones, D. S., Fike, D. A., Eisenman, I., Hughes, N. C., Tripati, A. K. \& Fischer, W. W. 2011: The magnitude and duration of Late Ordovician - Early Silurian glaciation. — Science 331/6019, 903-906. https://doi.org/10.1126/ science. 1200803

Gallagher, T. M. \& SHELdon, N. D. 2016: Combining soil water balance and clumped isotopes to understand the nature and timing of pedogenic carbonate formation. — Chemical Geology 435, 79-91. https://doi.org/10.1016/j.chemgeo.2016.04.023

Garzione, C. N., Hoke, G. D., Libarkin, J. C., Withers, S., MacFadden, B., Eiler, J., Ghosh, P. \& Mulch, A. 2008: Rise of the Andes. - Science 320/5881, 1304-1307. https://doi.org/10.1126/science.1148615

Ghosh, P., Adkins, J., Affek, H., Balta, B., Guo, W., Schauble, E. A., Schrag, D. \& Eiler, J. M. 2006a: ${ }^{13} \mathrm{C}-{ }^{18} \mathrm{O}$ bonds in carbonate minerals: A new kind of paleothermometer. — Geochimica et Cosmochimica Acta 70/6, 1439-1456. https://doi.org/10.1016/ j.gca.2005.11.014

Ghosh, P., Garzione, C. N. \& EILER, J. M. 2006b: Rapid uplift of the Altiplano revealed through ${ }^{13} \mathrm{C}-{ }^{18} \mathrm{O}$ bonds in paleosol carbonates. - Science 311/5760, 511-515. https://doi.org/10.1126/science.1119365

Ghosh, P., Eiler, J., CAmpana, S. E. \& FeEnEy, R. F. 2007: Calibration of the carbonate 'clumped isotope' paleothermometer for otoliths. — Geochimica et Cosmochimica Acta 71/11, 2736-2744. https://doi.org/10.1016/j.gca.2007.03.015

Gilbert, P. U. P. A., Bergmann, K. D., Myers, C. E., Marcus, M. A., DeVol, R. T., Sun, C.-Y., Blonsky, A. Z., Tamre, E., Zhao, J., Karan, E. A., TAmura, N., Lemer, S., Giuffre, A. J., Giribet, G., Eiler, J. M. \& Knoll, A. H. 2017: Nacre tablet thickness records formation temperature in modern and fossil shells. — Earth and Planetary Science Letters 460, 281-292. https://doi.org/10.1016/ j.epsl.2016.11.012

Grauel, A.-L., Schmid, T. W., Hu, B., Bergami, C., Capotondi, L., Zhou, L. \& Bernasconi, S. M. 2013: Calibration and application of the 'clumped isotope' thermometer to foraminifera for high-resolution climate reconstructions. - Geochimica et Cosmochimica Acta 108, 125-140. https://doi.org/10.1016/j.gca.2012.12.049

Grauel, A.-L., Hodell, D. A. \& Bernasconi, S. M. 2016: Quantitative estimates of tropical temperature change in lowland Central America during the last $42 \mathrm{ka}$. — Earth and Planetary Science Letters 438, 37-46. https://doi.org/10.1016/j.epsl.2016.01.001

GuO, W. 2008: Carbonate clumped isotope thermometry: application to carbonaceous chondrites \& effects of kinetic isotope fractionation. — PhD Thesis, California Institute of Technology, Pasadena, CA, USA, CaltechETD:etd-12182008-115035, 243 p.

Guo, W. \& EILER, J. M. 2007: Temperatures of aqueous alteration and evidence for methane generation on the parent bodies of the CM chondrites. — Geochimica et Cosmochimica Acta 71/22, 5565-5575. https://doi.org/10.1016/j.gca.2007.07.029

Guo, W., Mosenfelder, J. L., GodDARD, W. A. \& EILER, J. M. 2009: Isotopic fractionations associated with phosphoric acid digestion of carbonate minerals: Insights from first-principles theoretical modeling and clumped isotope measurements. - Geochimica et Cosmochimica Acta 73/24, 7203-7225. https://doi.org/10.1016/j.gca.2009.05.071

Halevy, I., Fischer, W. W. \& EILER, J. M. 2011: Carbonates in the Martian meteorite Allan Hills 84001 formed at $18 \pm 4{ }^{\circ} \mathrm{C}$ in a nearsurface aqueous environment. - Proceedings of the National Academy of Sciences of the United States of America 108/41, 1689516899. https://doi.org/10.1073/pnas.1109444108

He, B., Olack, G. A. \& Colman, A. S. 2012: Pressure baseline correction and high-precision $\mathrm{CO}_{2}$ clumped-isotope $\left(\Delta_{47}\right)$ measurements in bellows and micro-volume modes. — Rapid Communications in Mass Spectrometry 26/24, 2837-2853. https://doi.org/ $10.1002 / \mathrm{rcm} .6436$

Heimhofer, U., Meister, P., Bernasconi, S. M., Ariztegui, D., Martill, D. M., Rios-Netto, A. M. \& Schwark, L. 2017: Isotope and elemental geochemistry of black shale-hosted fossiliferous concretions from the Cretaceous Santana Formation fossil Lagerstätte (Brazil). — Sedimentology 64/1, 150-167. https://doi.org/10.1111/sed.12337 
Hendy, C. H. \& Wilson, A. T. 1968: Palaeoclimatic data from speleothems. - Nature 219/5149, 48-51. https://doi.org/ $10.1038 / 219048 \mathrm{a} 0$

Henkes, G. A., Passey, B. H., Wanamaker, A. D., Grossman, E. L., Ambrose, W. G. \& Carroll, M. L. 2013: Carbonate clumped isotope compositions of modern marine mollusk and brachiopod shells. - Geochimica et Cosmochimica Acta 106, 307-325. https://doi.org/10.1016/j.gca.2012.12.020

Henkes, G. A., Passey, B. H., Grossman, E. L., Shenton, B. J., Perez-Huerta, A. \& Yancey, T. E. 2014: Temperature limits for preservation of primary calcite clumped isotope paleotemperatures. - Geochimica et Cosmochimica Acta 139, 362-382. https://doi.org/10.1016/j.gca.2014.04.040

Hill, P. S., Tripati, A. K. \& Schauble, E. A. 2014: Theoretical constraints on the effects of pH, salinity, and temperature on clumped isotope signatures of dissolved inorganic carbon species and precipitating carbonate minerals. — Geochimica et Cosmochimica Acta 125, 610-652. https://doi.org/10.1016/j.gca.2013.06.018

Hodson, K. R., Crider, J. G. \& Huntington, K. W. 2016: Temperature and composition of carbonate cements record early structural control on cementation in a nascent deformation band fault zone: Moab Fault, Utah, USA. - Tectonophysics 690, $240-252$. https://doi.org/10.1016/j.tecto.2016.04.032

HoEfs, J. 2015: Stable Isotope Geochemistry. — Springer International Publishing, 389 p. https://doi.org/10.1007/978-3-319-19716-6

Hough, B. G., FAN, M. \& PASSEY, B. H. 2014: Calibration of the clumped isotope geothermometer in soil carbonate in Wyoming and Nebraska, USA: Implications for paleoelevation and paleoclimate reconstruction. _ Earth and Planetary Science Letters 391, 110_ 120. https://doi.org/10.1016/j.epsl.2014.01.008

Hu, B., RadKe, J., Schluter, H. J., Heine, F. T., Zhou, L. \& Bernasconi, S. M. 2014: A modified procedure for gas-source isotope ratio mass spectrometry: the long-integration dual-inlet (LIDI) methodology and implications for clumped isotope measurements. Rapid Communications in Mass Spectrometry 28/13, 1413-1425. https://doi.org/10.1002/rcm.6909

Huntington, K. W. \& LeChleR, A. R. 2015: Carbonate clumped isotope thermometry in continental tectonics. — Tectonophysics 647648, 1-20. https://doi.org/10.1016/j.tecto.2015.02.019

Huntington, K. W., Eiler, J. M., Affek, H. P., Guo, W., Bonifacie, M., Yeung, L. Y., Thiagarajan, N., Passey, B., Tripati, A., Daeron, M. \& CAME, R. 2009: Methods and limitations of 'clumped' $\mathrm{CO}_{2}$ isotope $\left(\Delta_{47}\right)$ analysis by gas-source isotope ratio mass spectrometry. — Journal of Mass Spectrometry 44/9, 1318-1329. https://doi.org/10.1002/jms.1614

Huntington, K. W., Budd, D. A., Wernicke, B. P. \& Eiler, J. M. 2011: Use of clumped-isotope thermometry to constrain the crystallization temperature of diagenetic calcite. — Journal of Sedimentary Research 81/9, 656-669. https://doi.org/10.2110/ jsr.2011.51

Inagaki, F., Hinrichs, K. U., Kubo, Y., Bowles, M. W., Heuer, V. B., Hong, W. L., Hoshino, T., Ijiri, A., Imachi, H., Ito, M., Kaneko, M., Lever, M. A., Lin, Y. S., Methe, B. A., Morita, S., Morono, Y., Tanikawa, W., Bihan, M., Bowden, S. A., Elvert, M., Glombitza, C., Gross, D., Harrington, G. J., Hori, T., Li, K., Limmer, D., Liu, C. H., Murayama, M., Ohkouchi, N., Ono, S., Park, Y. S., Phillips, S. C., Prieto-Mollar, X., Purkey, M., Riedinger, N., Sanada, Y., Sauvage, J., Snyder, G., Susilawati, R., Takano, Y., Tasumi, E., Terada, T., Tomaru, H., Trembath-Reichert, E., Wang, D. T. \& Yamada, Y. 2015: Exploring deep microbial life in coal-bearing sediment down to $\sim 2.5 \mathrm{~km}$ below the ocean floor. — Science 349/6246, 420-424. https://doi.org/ $10.1126 /$ science.aaa6882

John, C. M. \& Bowen, D. 2016: Community software for challenging isotope analysis: First applications of 'Easotope' to clumped isotopes. - Rapid Communications in Mass Spectrometry 30/21, 2285-2300. https://doi.org/10.1002/rcm.7720

Kar, N., Garzione, C. N., Jaramillo, C., Shanahan, T., Carlotto, V., Pullen, A., Moreno, F., Anderson, V., Moreno, E. \& Eiler, J. 2016: Rapid regional surface uplift of the northern Altiplano plateau revealed by multiproxy paleoclimate reconstruction. — Earth and Planetary Science Letters 447, 33-47. https://doi.org/10.1016/j.eps1.2016.04.025

Kele, S., Breitenbach, S. F. M., Capezzuoli, E., Nele Meckler, A., Ziegler, M., Millan, I. M., Kluge, T., Deák, J., Hanselmann, K., John, C. M., YAn, H., LiU, Z. \& Bernasconi, S. M. 2015: Temperature dependence of oxygen- and clumped isotope fractionation in carbonates: a study of travertines and tufas in the $6-95^{\circ} \mathrm{C}$ temperature range. - Geochimica et Cosmochimica Acta 168, $172-192$. https://doi.org/10.1016/j.gca.2015.06.032

Kelson, J. R., Huntington, K. W., Schauer, A. J., SAenger, C. \& Lechler, A. R. 2017: Toward a universal carbonate clumped isotope calibration: Diverse synthesis and preparatory methods suggest a single temperature relationship. — Geochimica et Cosmochimica Acta 197, 104-131. https://doi.org/10.1016/j.gca.2016.10.010

Kimball, J., Eagle, R. \& DunbaR, R. 2016: Carbonate "clumped” isotope signatures in aragonitic scleractinian and calcitic gorgonian deep-sea corals. — Biogeosciences 13/23, 6487-6505. https://doi.org/10.5194/bg-13-6487-2016

KLuge, T. \& AfFeK, H. P. 2012: Quantifying kinetic fractionation in Bunker Cave speleothems using $\Delta_{47}$ - Q Quaternary Science Reviews 49, 82-94. https://doi.org/10.1016/j.quascirev.2012.06.013

Kluge, T., Affek, H. P., Marx, T., Aeschbach-Hertig, W., Riechelmann, D. F. C., Scholz, D., Riechelmann, S., Immenhauser, A., Richter, D. K., Fohlmeister, J., Wackerbarth, A., Mangini, A. \& Spötl, C. 2013: Reconstruction of drip-water ${ }^{18} \mathrm{O}$ based on calcite oxygen and clumped isotopes of speleothems from Bunker Cave (Germany). - Climate of the Past 9/1, 377-391. https://doi.org/10.5194/cp-9-377-2013

Kluge, T., AffeK, H. P., Zhang, Y. G., Dublyansky, Y., Spötl, C., Immenhauser, A. \& Richter, D. K. 2014: Clumped isotope thermometry of cryogenic cave carbonates. - Geochimica et Cosmochimica Acta 126, 541-554. https://doi.org/10.1016/ j.gca.2013.11.011

KLUGE, T. \& JoHn, C. M. 2015: Effects of brine chemistry and polymorphism on clumped isotopes revealed by laboratory precipitation of mono- and multiphase calcium carbonates. — Geochimica et Cosmochimica Acta 160, 155-168. https://doi.org/10.1016/ j.gca.2015.03.031 
Kluge, T., John, C. M., Jourdan, A.-L., Davis, S. \& CRAwshaW, J. 2015: Laboratory calibration of the calcium carbonate clumped isotope thermometer in the $25-250^{\circ} \mathrm{C}$ temperature range. - Geochimica et Cosmochimica Acta 157, 213-227. https://doi.org/ 10.1016/j.gca.2015.02.028

Li, S., Yeung, L. Y., Young, E. D., Ostrom, N. E. \& Haslun, J. A. 2016: Triple-isotopologue Analysis of N 2 as a Tracer of the Global Nitrogen Cycle. — 5th International Clumped Isotope Workshop, St. Petersburg, Florida, p. 29.

LIU, Q. \& LIU, Y. 2016: Clumped-isotope signatures at equilibrium of $\mathrm{CH}_{4}, \mathrm{NH}_{3}, \mathrm{H}_{2} \mathrm{O}, \mathrm{H}_{2} \mathrm{~S}_{\text {and }} \mathrm{SO}_{2}$. - Geochimica et Cosmochimica Acta 175, 252-270. https://doi.org/10.1016/j.gca.2015.11.040

Lloyd, M. K., EILER, J. M. \& NABeleK, P. I. 2017: Clumped isotope thermometry of calcite and dolomite in a contact metamorphic environment. — Geochimica et Cosmochimica Acta 197, 323-344. https://doi.org/10.1016/j.gca.2016.10.037

Loyd, S. J., Dickson, J. A. D., Scholle, P. A. \& TrIPATI, A. K. 2013: Extensive, uplift-related and non-fault-controlled spar precipitation in the Permian Capitan Formation. — Sedimentary Geology 298, 17-27. https://doi.org/10.1016/j.sedgeo.2013.10.001

Loyd, S. J., Corsetti, F. A., Eagle, R. A., Hagadorn, J. W., Shen, Y., Zhang, X., Bonifacie, M. \& Tripati, A. K. 2015: Evolution of Neoproterozoic Wonoka-Shuram Anomaly-aged carbonates: evidence from clumped isotope paleothermometry. — Precambrian Research 264, 179-191. https://doi.org/10.1016/j.precamres.2015.04.010

Luetkemeyer, P. B., Kirschner, D. L., Huntington, K. W., Chester, J. S., Chester, F. M. \& Evans, J. P. 2016 : Constraints on paleofluid sources using the clumped-isotope thermometry of carbonate veins from the SAFOD (San Andreas Fault Observatory at Depth) borehole. - Tectonophysics 690, 174-189. https://doi.org/10.1016/j.tecto.2016.05.024

MacDonald, J., John, C. \& GIRARD, J.-P. 2015: Dolomitization processes in hydrocarbon reservoirs: insight from geothermometry using clumped isotopes. — Procedia Earth and Planetary Science 13, 265-268. https://doi.org/10.1016/j.proeps.2015.07.062

MCCREA, J. M. 1950: On the Isotopic Chemistry of Carbonates and a Paleotemperature Scale. - The Journal of Chemical Physics 18/6, 849-857. https://doi.org/10.1063/1.1747785

Meckler, A. N., Ziegler, M., Millan, M. I., Breitenbach, S. F. \& Bernasconi, S. M. 2014: Long-term performance of the Kiel carbonate device with a new correction scheme for clumped isotope measurements. — Rapid Communications in Mass Spectrometry 28/15, 1705-1715. https://doi.org/10.1002/rcm.6949

Meckler, A. N., Affolter, S., Dublyansky, Y. V., Krüger, Y., Vogel, N., Bernasconi, S. M., Frenz, M., Kipfer, R., Leuenberger, M., Spötl, C., Carolin, S., Cobb, K. M., Moerman, J., Adkins, J. F. \& Fleitmann, D. 2015: Glacial-interglacial temperature change in the tropical West Pacific: A comparison of stalagmite-based paleo-thermometers. — Quaternary Science Reviews 127, 90-116. https://doi.org/10.1016/j.quascirev.2015.06.015

Methner, K., Mulch, A., Fiebig, J., Wacker, U., Gerdes, A., Graham, S. A. \& Chamberlain, C. P. 2016: Rapid Middle Eocene temperature change in western North America. — Earth and Planetary Science Letters 450, 132-139. https:/doi.org/10.1016/ j.eps1.2016.05.053

Millán, M. I., Machel, H. \& Bernasconi, S. M. 2016: Constraining temperatures of formation and composition of dolomitizing fluids in the Upper Devonian Nisku Formation (Alberta, Canada) with clumped isotopes. _ Journal of Sedimentary Research 86/2, 107112. https://doi.org/10.2110/jsr.2016.6

Mroz, E. J., Alei, M., Cappis, J. H., Guthals, P. R., Mason, A. S. \& Rokop, D. J. 1989: Detection of multiply deuterated methane in the atmosphere. — Geophysical Research Letters 16/7, 677-678. https://doi.org/DOI 10.1029/GL016i007p00677

Müller, I. A., Violay, M. E. S., Storck, J.-C., Fernandez, A., van Dijk, J., Madonna, C. \& Bernasconi, S. M. 2017: Clumped isotope fractionation during phosphoric acid digestion of carbonates at $70{ }^{\circ} \mathrm{C}$. — Chemical Geology 449, 1-14. https://doi.org/10.1016/ j.chemgeo.2016.11.030

Murray, S. T., Arienzo, M. M. \& Swart, P. K. 2016: Determining the $\Delta_{47}$ acid fractionation in dolomites. - Geochimica et Cosmochimica Acta 174, 42-53. https://doi.org/10.1016/j.gca.2015.10.029

Ono, S., Wang, D. T., Gruen, D. S., Sherwood Lollar, B., Zahniser, M. S., McManus, B. J. \& Nelson, D. D. 2014: Measurement of a doubly substituted methane isotopologue, ${ }^{13} \mathrm{CH}_{3} \mathrm{D}$, by tunable infrared laser direct absorption spectroscopy. — Analitical Chemistry 86/13, 6487-6494. https://doi.org/10.1021/ac5010579

Passey, B. H., Levin, N. E., Cerling, T. E., Brown, F. H. \& Eiler, J. M. 2010: High-temperature environments of human evolution in East Africa based on bond ordering in paleosol carbonates. — Proceedings of the National Academy of Sciences of the United States of America 107/25, 11245-11249. https://doi.org/10.1073/pnas.1001824107

Passey, B. H. \& Henkes, G. A. 2012: Carbonate clumped isotope bond reordering and geospeedometry. — Earth and Planetary Science Letters 351-352, 223-236. https://doi.org/10.1016/j.eps1.2012.07.021

Peters, N. A., Huntington, K. W. \& Hoke, G. D. 2013: Hot or not? Impact of seasonally variable soil carbonate formation on paleotemperature and O-isotope records from clumped isotope thermometry. — Earth and Planetary Science Letters 361, $208-218$. https://doi.org/10.1016/j.eps1.2012.10.024

Petersen, S. V., Winkelstern, I. Z., Lohmann, K. C. \& Meyer, K. W. 2016a: The effects of Porapak trap temperature on $\delta^{18}$ O, $\delta^{13}$ C, and $\Delta_{47}$ values in preparing samples for clumped isotope analysis. — Rapid Communications in Mass Spectrometry 30/1, 199-208. https://doi.org/10.1002/rcm.7438

Petersen, S. V., Dutton, A. \& Lohmann, K. C. 2016b: End-Cretaceous extinction in Antarctica linked to both Deccan volcanism and meteorite impact via climate change. — Nature Communications 7/12079, 1-9. https://doi.org/10.1038/ncomms12079

Petersen, S. V., Tabor, C. R., Lohmann, K. C., Poulsen, C. J., Meyer, K. W., Carpenter, S. J., Erickson, J. M., Matsunaga, K. K. S., Smith, S. Y. \& Sheldon, N. D. 2016c: Temperature and salinity of the Late Cretaceous Western Interior Seaway. - Geology 44/11, 903-906. https://doi.org/10.1130/g38311.1

Petrizzo, D. A. \& Young, E. D. 2014: High-precision determination of ${ }^{13} \mathrm{C}-{ }^{18} \mathrm{O}$ bonds in $\mathrm{CO}_{2}$ using multicollector peak hopping. — Rapid Communications in Mass Spectrometry 28/11, 1185-1193. https://doi.org/10.1002/rcm.6888 
Petryshyn, V. A., Rivera, M. J., Agić, H., Frantz, C. M., Corsetti, F. A. \& Tripati, A. E. 2016: Stromatolites in Walker Lake (Nevada, Great Basin, USA) record climate and lake level changes $~ 35,000$ years ago. - Palaeogeography, Palaeoclimatology, Palaeoecology 451, 140-151. https://doi.org/10.1016/j.palaeo.2016.02.054

Piasecki, A., Sessions, A., Peterson, B. \& Eiler, J. 2016: Prediction of equilibrium distributions of isotopologues for methane, ethane and propane using density functional theory. — Geochimica et Cosmochimica Acta 190, 1-12. https://doi.org/10.1016/ j.gca.2016.06.003

PRICE, G. D. \& PASSEY, B. H. 2013: Dynamic polar climates in a greenhouse world: Evidence from clumped isotope thermometry of Early Cretaceous belemnites. — Geology 41/8, 923-926. https://doi.org/10.1130/g34484.1

Quade, J., Garzione, C. \& Eiler, J. 2007: Paleoelevation Reconstruction using Pedogenic Carbonates. — Reviews in Mineralogy and Geochemistry 66/1, 53-87. https://doi.org/10.2138/rmg.2007.66.3

Quade, J., Eiler, J., DaËron, M. \& Achyuthan, H. 2013: The clumped isotope geothermometer in soil and paleosol carbonate. Geochimica et Cosmochimica Acta 105, 92-107. https://doi.org/10.1016/j.gca.2012.11.031

Quesnel, B., Boulvais, P., Gautier, P., Cathelineau, M., John, C. M., Dierick, M., Agrinier, P. \& Drouillet, M. 2016: Paired stable isotopes $(\mathrm{O}, \mathrm{C})$ and clumped isotope thermometry of magnesite and silica veins in the New Caledonia Peridotite Nappe. Geochimica et Cosmochimica Acta 183, 234-249. https://doi.org/10.1016/j.gca.2016.03.021

Ringham, M. C., Hoke, G. D., Huntington, K. W. \& Aranibar, J. N. 2016: Influence of vegetation type and site-to-site variability on soil carbonate clumped isotope records, Andean piedmont of Central Argentina (32-34 $\left.{ }^{\circ} \mathrm{S}\right)$. — Earth and Planetary Science Letters 440, 1-11. https://doi.org/10.1016/j.epsl.2016.02.003

Ritter, A.-C., Kluge, T., Berndt, J., Richter, D. K., John, C. M., Bodin, S. \& Immenhauser, A. 2015: Application of redox sensitive proxies and carbonate clumped isotopes to Mesozoic and Palaeozoic radiaxial fibrous calcite cements. — Chemical Geology 417, 306-321. https://doi.org/10.1016/j.chemgeo.2015.10.008

Ritter, A.-C., Mavromatis, V., Dietzel, M., Kwiecien, O., Wiethoff, F., Griesshaber, E., Casella, L. A., Schmahl, W. W., Koelen, J., Neuser, R. D., Leis, A., Buhl, D., Niedermayr, A., Breitenbach, S. F. M., Bernasconi, S. M. \& Immenhauser, A. 2017: Exploring the impact of diagenesis on (isotope) geochemical and microstructural alteration features in biogenic aragonite. Sedimentology. https://doi.org/10.1111/sed.12356

Röckmann, T., Popa, M. E., Krol, M. C. \& Hofmann, M. E. 2016: Statistical clumped isotope signatures. — Scientific Reports 6/31947, 1-14. https://doi.org/10.1038/srep31947

Rosenheim, B. E., TANG, J. \& Fernandez, A. 2013: Measurement of multiply substituted isotopologues ('clumped isotopes') of $\mathrm{CO}_{2}$ using a $5 \mathrm{kV}$ compact isotope ratio mass spectrometer: performance, reference frame, and carbonate paleothermometry. — Rapid Communications in Mass Spectrometry 27/16, 1847-1857. https://doi.org/10.1002/rcm.6634

Rosman, K. J. R. \& TAYLOR, P. D. P. 1998: Isotopic Compositions of the Elements 1997: Technical Report. — Pure and Applied Chemistry 70/1, 217-235.

Saenger, C., Affek, H. P., Felis, T., Thiagarajan, N., Lough, J. M. \& Holcomb, M. 2012: Carbonate clumped isotope variability in shallow water corals: Temperature dependence and growth-related vital effects. — Geochimica et Cosmochimica Acta 99, $224-242$. https://doi.org/10.1016/j.gca.2012.09.035

Sample, J. C., Torres, M. E., Fisher, A., Hong, W.-L., Destrigneville, C., Defliese, W. F. \& Tripati, A. E. 2017: Geochemical constraints on the temperature and timing of carbonate formation and lithification in the Nankai Trough, NanTroSEIZE transect. Geochimica et Cosmochimica Acta 198, 92-114. https://doi.org/10.1016/j.gca.2016.10.013

Schauble, E. A., Ghosh, P. \& Eiler, J. M. 2006: Preferential formation of ${ }^{13} \mathrm{C}-{ }^{18} \mathrm{O}$ bonds in carbonate minerals, estimated using firstprinciples lattice dynamics. — Geochimica et Cosmochimica Acta 70/10, 2510-2529. https://doi.org/10.1016/j.gca.2006.02.011

Schmid, T. W. 2011: Clumped-isotopes - A new tool for old questions - Case studies on biogenic and inorganic carbonates. - PhD Thesis, ETH Zürich, DISS ETH NO. 19607, 172 p.

SCHMID, T. W. \& Bernasconi, S. M. 2010: An automated method for 'clumped-isotope' measurements on small carbonate samples. Rapid Communications in Mass Spectrometry 24/14, 1955-1963. https://doi.org/10.1002/rcm.4598

SChmid, T. W., RADKE, J. \& BernasConi, S. M. 2012: Clumped-isotope measurements on small carbonate samples with a Kiel IV carbonate device and a MAT 253 mass spectrometer. — Thermo Fisher Application Note 30233, 3.

Sena, C. M., John, C. M., Jourdan, A. L., Vandeginste, V. \& Manning, C. 2014: Dolomitization of Lower Cretaceous peritidal carbonates by modified seawater: constraints from clumped isotopic paleothermometry, elemental chemistry, and strontium isotopes. — Journal of Sedimentary Research 84/7, 552-566. https://doi.org/10.2110/jsr.2014.45

Sharp, Z. 2007: Principles of Stable Isotope Geochemistry. — Pearson Education, Upper Saddle River, NJ, USA, 344 p.

Shenton, B. J., Grossman, E. L., Passey, B. H., Henkes, G. A., Becker, T. P., Laya, J. C., Perez-Huerta, A., Becker, S. P. \& Lawson, M. 2015: Clumped isotope thermometry in deeply buried sedimentary carbonates: The effects of bond reordering and recrystallization. — Geological Society of America Bulletin 127/7-8, 1036-1051. https://doi.org/10.1130/B31169.1

Siman-Tov, S., Affek, H. P., Matthews, A., Aharonov, E. \& Reches, Z. E. 2016: Shear heating and clumped isotope reordering in carbonate faults. — Earth and Planetary Science Letters 445, 136-145. https://doi.org/10.1016/j.eps1.2016.03.041

Snell, K. E., Koch, P. L., Druschke, P., Foreman, B. Z. \& Eiler, J. M. 2014: High elevation of the 'Nevadaplano' during the Late Cretaceous. — Earth and Planetary Science Letters 386, 52-63. https://doi.org/10.1016/j.epsl.2013.10.046

Spooner, P. T., Guo, W., Robinson, L. F., Thiagarajan, N., Hendry, K. R., Rosenheim, B. E. \& Leng, M. J. 2016: Clumped isotope composition of cold-water corals: A role for vital effects? - Geochimica et Cosmochimica Acta 179, 123-141. https://doi.org/ 10.1016/j.gca.2016.01.023

STAUDIGEL, P. T. \& SwART, P. K. 2016: Isotopic behavior during the aragonite-calcite transition: Implications for sample preparation and proxy interpretation. — Chemical Geology 442, 130-138. https://doi.org/10.1016/j.chemgeo.2016.09.013 
StOlPER, D. A. \& EILER, J. M. 2016: Constraints on the formation and diagenesis of phosphorites using carbonate clumped isotopes. Geochimica et Cosmochimica Acta 181, 238-259. https://doi.org/10.1016/j.gca.2016.02.030

Stolper, D. A., Sessions, A. L., Ferreira, A. A., Santos Neto, E. V., Schimmelmann, A., Shusta, S. S., Valentine, D. L. \& Eiler, J. M. 2014a: Combined ${ }^{13} \mathrm{C}-\mathrm{D}$ and D-D clumping in methane: Methods and preliminary results. — Geochimica et Cosmochimica Acta 126, 169-191. https://doi.org/10.1016/j.gca.2013.10.045

Stolper, D. A., Lawson, M., Davis, C. L., Ferreira, A. A., Santos Neto, E. V., Ellis, G. S., Lewan, M. D., Martini, A. M., Tang, Y., Schoell, M., Sessions, A. L. \& EILER, J. M. 2014b: Formation temperatures of thermogenic and biogenic methane. - Science 344/6191, 1500-1503. https://doi.org/10.1126/science.1254509

Stolper, D. A., Martini, A. M., Clog, M., Douglas, P. M., Shusta, S. S., Valentine, D. L., Sessions, A. L. \& Eiler, J. M. 2015: Distinguishing and understanding thermogenic and biogenic sources of methane using multiply substituted isotopologues. — Geochimica et Cosmochimica Acta 161, 219-247. https://doi.org/10.1016/j.gca.2015.04.015

Streit, E., Kelemen, P. \& EILER, J. 2012: Coexisting serpentine and quartz from carbonate-bearing serpentinized peridotite in the Samail Ophiolite, Oman. — Contributions to Mineralogy and Petrology 164/5, 821-837. https://doi.org/10.1007/s00410-012-0775-z

SuAREZ, M. B. \& PASSEY, B. H. 2014: Assessment of the clumped isotope composition of fossil bone carbonate as a recorder of subsurface temperatures. — Geochimica et Cosmochimica Acta 140, 142-159. https://doi.org/10.1016/j.gca.2014.05.026

Sumner, K. K., Camp, E. R., Huntington, K. W., Cladouhos, T. T. \& Uddenberg, M. 2015: Assessing Fracture Connectivity using Stable and Clumped Isotope Geochemistry of Calcite Cements. — Fortieth Workshop on Geothermal Reservoir Engineering, Stanford, California, SGP-TR-204, pp. 1-12.

Swanson, E. M., Wernicke, B. P., EILER, J. M. \& Losh, S. 2012: Temperatures and fluids on faults based on carbonate clumped-isotope thermometry. - American Journal of Science 312/1, 1-21. https://doi.org/10.2475/01.2012.01

Tang, J., Dietzel, M., Fernandez, A., Tripati, A. K. \& Rosenheim, B. E. 2014: Evaluation of kinetic effects on clumped isotope fractionation $\left(\Delta_{47}\right)$ during inorganic calcite precipitation. — Geochimica et Cosmochimica Acta 134, 120-136. https://doi.org/ 10.1016/j.gca.2014.03.005

Thiagarajan, N., AdKIns, J. \& EILER, J. 2011: Carbonate clumped isotope thermometry of deep-sea corals and implications for vital effects. - Geochimica et Cosmochimica Acta 75/16, 4416-4425. https://doi.org/10.1016/j.gca.2011.05.004

Thompson, P., Schwarcz, H. P. \& Ford, D. C. 1974: Continental Pleistocene climatic variations from speleothem age and isotopic data. - Science 184/4139, 893-895. https://doi.org/10.1126/science.184.4139.893

Tremaine, D. M., Froelich, P. N. \& WANG, Y. 2011: Speleothem calcite farmed in situ: Modern calibration of $\delta^{18} \mathrm{O}$ and ${ }^{13} \mathrm{C}$ paleoclimate proxies in a continuously-monitored natural cave system. — Geochimica et Cosmochimica Acta 75/17, 4929-4950. https://doi.org/ 10.1016/j.gca.2011.06.005

Tripati, A. K., Eagle, R. A., Thiagarajan, N., Gagnon, A. C., Bauch, H., Halloran, P. R. \& Eiler, J. M. 2010: ${ }^{13}$ C- ${ }^{18}$ O isotope signatures and 'clumped isotope' thermometry in foraminifera and coccoliths. _ Geochimica et Cosmochimica Acta 74/20, 56975717. https://doi.org/10.1016/j.gca.2010.07.006

Tripati, A. K., Hill, P. S., Eagle, R. A., Mosenfelder, J. L., Tang, J., Schauble, E. A., Eiler, J. M., Zeebe, R. E., Uchikawa, J., Coplen, T. B., RIES, J. B. \& HENRY, D. 2015: Beyond temperature: Clumped isotope signatures in dissolved inorganic carbon species and the influence of solution chemistry on carbonate mineral composition. - Geochimica et Cosmochimica Acta 166, 344-371. https://doi.org/10.1016/j.gca.2015.06.021

Tsuj, K., Teshima, H., SASADA, H. \& YoshidA, N. 2012: Spectroscopic isotope ratio measurement of doubly-substituted methane. Spectrochimica Acta Part A: Molecular and Biomolecular Spectroscopy 98, 43-46. https://doi.org/10.1016/j.saa.2012.08.028

UREY, H. C. 1947: The thermodynamic properties of isotopic substances. — Journal of the Chemical Society, 562-581. https://doi.org/ $0.1039 / J R 9470000562$

van Dijk, J., Fernandez, A., Müller, I. A., White, T., Lever, M. \& Bernasconi, S. M. 2016: Microbially-mediated and abiotic synthesis of siderite from 10 to $70^{\circ} \mathrm{C}$ : a new $\Delta_{47}$ and $\delta^{18} \mathrm{O}$ calibration. - 5th International Clumped Isotope Workshop, St. Petersburg, Florida, p. 14.

Vandeginste, V., John, C. M., Cosgrove, J. W. \& Manning, C. 2014: Dimensions, texture-distribution, and geochemical heterogeneities of fracture-related dolomite geobodies hosted in Ediacaran limestones, northern Oman. — AAPG Bulletin 98/9, 1789-1809. https://doi.org/10.1306/05121413127

VanDeVelde, J. H., Bowen, G. J., PAssey, B. H. \& Bowen, B. B. 2013: Climatic and diagenetic signals in the stable isotope geochemistry of dolomitic paleosols spanning the Paleocene-Eocene boundary. — Geochimica et Cosmochimica Acta 109, $254-267$. https://doi.org/10.1016/j.gca.2013.02.005

WaCKer, U., Fiebig, J. \& Schoene, B. R. 2013: Clumped isotope analysis of carbonates: comparison of two different acid digestion techniques. — Rapid Communications in Mass Spectrometry 27/14, 1631-1642. https://doi.org/10.1002/rcm.6609

Wacker, U., Fiebig, J., Tödter, J., Schöne, B. R., Bahr, A., Friedrich, O., Tütken, T., Gischler, E. \& Joachimski, M. M. 2014: Empirical calibration of the clumped isotope paleothermometer using calcites of various origins. - Geochimica et Cosmochimica Acta 141, 127-144. https://doi.org/10.1016/j.gca.2014.06.004

Wacker, U., Rutz, T., Löffler, N., Conrad, A. C., Tütken, T., Böttcher, M. E. \& FiebiG, J. 2016: Clumped isotope thermometry of carbonate-bearing apatite: Revised sample pre-treatment, acid digestion, and temperature calibration. — Chemical Geology 443, 97110. https://doi.org/10.1016/j.chemgeo.2016.09.009

Wainer, K., Genty, D., Blamart, D., Dä̈ron, M., Bar-Matthews, M., Vonhof, H., Dublyansky, Y., Pons-Branchu, E., Thomas, L., VAN CALsteren, P., Quinif, Y. \& CAILlon, N. 2011: Speleothem record of the last 180 ka in Villars cave (SW France): Investigation of a large $\delta^{18} \mathrm{O}$ shift between MIS6 and MIS5. — Quaternary Science Reviews 30/1-2, 130-146. https://doi.org/10.1016/ j.quascirev.2010.07.004 
WANG, Z., SchaUble, E. A. \& EILER, J. M. 2004: Equilibrium thermodynamics of multiply substituted isotopologues of molecular gases. — Geochimica et Cosmochimica Acta 68/23, 4779-4797. https://doi.org/10.1016/j.gca.2004.05.039

WANG, D. T., Welander, P. V. \& ONO, S. 2016: Fractionation of the methane isotopologues ${ }^{13} \mathrm{CH}_{4},{ }^{12} \mathrm{CH}_{3} \mathrm{D}$, and ${ }^{13} \mathrm{CH}_{3} \mathrm{D}$ during aerobic oxidation of methane by Methylococcus capsulatus (Bath). — Geochimica et Cosmochimica Acta 192, 186-202. https://doi.org/ 10.1016/j.gca.2016.07.031

WatKInS, J. M. \& HunT, J. D. 2015: A process-based model for non-equilibrium clumped isotope effects in carbonates. — Earth and Planetary Science Letters 432, 152-165. https://doi.org/10.1016/j.eps1.2015.09.042

Webb, M. A., Wang, Y., BraAms, B. J., Bowman, J. M. \& Miller, T. F. 2017: Equilibrium clumped-isotope effects in doubly substituted isotopologues of ethane. - Geochimica et Cosmochimica Acta 197, 14-26. https://doi.org/10.1016/j.gca.2016.10.001

WinkELSTERN, I. Z. \& LOHMANN, K. C. 2016: Shallow burial alteration of dolomite and limestone clumped isotope geochemistry. Geology 44/6, 467-470. https://doi.org/10.1130/g37809.1

Winkelstern, I. Z., KaczmareK, S. E., Lohmann, K. C. \& Humphrey, J. D. 2016: Calibration of dolomite clumped isotope thermometry. - Chemical Geology 443, 32-38. https://doi.org/10.1016/j.chemgeo.2016.09.021

Yeung, L. Y. 2016: Combinatorial effects on clumped isotopes and their significance in biogeochemistry. - Geochimica et Cosmochimica Acta 172, 22-38. https://doi.org/10.1016/j.gca.2015.09.020

Yeung, L. Y., Young, E. D. \& Schauble, E. A. 2012: Measurements of ${ }^{18} \mathrm{O}^{18} \mathrm{O}$ and ${ }^{17} \mathrm{O}^{18} \mathrm{O}$ in the atmosphere and the role of isotopeexchange reactions. — Journal of Geophysical Research: Atmospheres 117/D18306, 1-20. https://doi.org/10.1029/2012jd017992

Yeung, L. Y., Ash, J. L. \& Young, E. D. 2014: Rapid photochemical equilibration of isotope bond ordering in $\mathrm{O}_{2}$. - Journal of Geophysical Research: Atmospheres 119/17, 10552-10566. https://doi.org/10.1002/2014jd021909

Yeung, L. Y., Ash, J. L. \& Young, E. D. 2015: Biological signatures in clumped isotopes of $\mathrm{O}_{2}$. — Science 348/6233, $431-434$. https://doi.org/10.1126/science.aaa6284

Yoshida, N., Vasilev, M., Ghosh, P., Abe, O., Yamada, K. \& Morimoto, M. 2013: Precision and long-term stability of clumped-isotope analysis of $\mathrm{CO}_{2}$ using a small-sector isotope ratio mass spectrometer. - Rapid Communications in Mass Spectrometry 27, $207-215$. https://doi.org/10.1002/rcm.6431

ZaArur, S., AfFeK, H. P. \& Brandon, M. T. 2013: A revised calibration of the clumped isotope thermometer. — Earth and Planetary Science Letters 382, 47-57. https://doi.org/10.1016/j.eps1.2013.07.026

Kézirat beérkezett: 2016. 10. 27. 